\title{
A NACIONALIZAÇão do GÁS E PETRÓleO NA BOLÍVIA À LUZ DO DIREITO INTER.NACIONAL
}

\author{
THE NATIONALIZATION OF GAS AND OIL IN BOLIVIA ACCORDING TO INTERNATIONAL LAW
}

\section{Roberto Chacon de Albuquerque}

\begin{abstract}
Resumo:
O Autor analisa a mais recente nacionalização do gás e petróleo na Bolivia. Ela é examinada com base $\mathrm{cm}$ fontes primárias. A expropriação de empresas estrangeiras não é um fato inédito na história da Bolívia. Sua legitimidade sob o ponto de vista do Direito Internacional vincula-se ao pagamento de indenização.
\end{abstract}

Palavras-chave: Nacionalização. Expropriação. Gás. Petróleo. Petrobras. Bolívia. Abstract:

The Author analyzes the most recent gas and oil nationalization in Bolivia. This expropriation of foreign companies did not happen for the first time ever in Bolivia's history. Its legitimacy under the standpoint of International Law is connected to the payment of compensation.

Keywords: Nationalization. Expropriation. Gas. Oil. Petrobras. Bolivia.

\section{Introdução}

A Bolivia anunciou, em $1^{\circ}$ de maio de 2006, a nacionalização do gás e petróleo. Militares assumiram o controle de 56 instalações petrolíferas. A Bolívia recuperava assim suas riquezas naturais. As jazidas de gás e petróleo, no entanto, já haviam sido nacionalizadas há muito tempo. À luz da Constituição boliviana, elas pertenciam ao Estado. O governo celebrava contratos de concessão com empresas estrangeiras para a prospeç̧ão, exploração e comercialização de hidrocarbonetos'. Através de licitações públicas internacionais, empresas estrangeiras eram selecionadas para explorar gás e petróleo numa área contratada. Os contratos de concessão não compreendiam a transferência da propriedade das jazidas de gás e petróleo. Elas continuavam sempre a pertencer ao Estado.

Não houve, portanto, uma nacionalização do gás e petróleo, mas uma expropriação de empresas estrangeiras que efetuavam a prospecção. exploração e comercialização de hidrocarbonetos com base em contratos que haviam sido celebrados

\footnotetext{
Advogado, doutor em Direito Internacional pela Faculdade de Direito da Universidade São Paulo.

"Hidrocarbonetos" é um termo que costuma ser utilizado correntemente na Bolivia para designar o gás e petróleo. Tecnicamente, hidrocarboneto é o composto quimico formado por carbono e hidrogênio. O gás nalural é um hidrocarboneto gasoso, enquanto o petróleo é um hidrocarboneto líquido.
} 
com o Fstado boliviano, o qual permanecia sempre como proprietário das jazidas de gás e petróleo de maneira direta. inalienável e imprescritível. Um dos problemas fundamentais da expropriação de empresas estrangeiras é a insegurança jurídica que ela gera. Pode contrariar tratados. bem como decisões abalizadas de tribunais internacionais. A expropriação não ocorre necessariamente com o confisco dos ativos das empresas, mas também com a adoção de impostos discriminatórios e abusivos que inviabilizem seu funcionamento. Mesmo se for considerada de utilidade pública, tendo como meta, por exemplo, a industrialização autóctone do gás e petróleo, a expropriação dá lugar a indenização às empresas estrangeiras afetadas. Toda nacionalização constitui uma decisão eminentemente política. Requer apoio social genuíno, consciente de suas necessidades, implicações e repercussões.

O lucro com a exploração do gás e petróleo pode ser definido como a diferença entre o preço de mercado, por um lado, e, por outro lado, os custos de produção acrescidos de um montante para custos adicionais transporte, processamento c distribuição e do retorno para o capital investido. Quando o preço do gás e petróleo aumenta, como ocorre atualmente, fortalece-se a posição dos Estados com hidrocarbonetos para aumentar sua participação no lucro com a exploração de suas jazidas. Contratos de risco compartilhado ${ }^{2}$ entre empresas estrangeiras e a respectiva empresa estatal do gás e petróleo podem ser revistos, novos impostos podem ser adotados, royalties, a compensação financeira devida pelos concessionários, podem ser majorados. Em casos extremos, pode ocorrer a expropriação das empresas estrangeiras que exploram hidrucarbonetos. A situação inverte-se quando o preço do gás e petróleo diminui. O poder de negociação das empresas estrangeiras fortalece-se, já que muitos países produtores de hidrocarbonetos começam a competir por seus investimentos. Os níveis de apropriação da renda pelo Estado (government take ${ }^{3}$ ) mediante impostos e royalties são decisivos para decidir onde investir. A Bolívia tem seguido esta dinâmica que acabamos de descrever de maneira consistente. Quando o preço do gás e petróleo se reduz, negociam-se contratos de concessão de maneira favorável com empresas estrangeiras. À medida que o preço do gás e petróleo aumenta, são adotadas medidas que elevam sistematicamente os níveis de apropriação da renda pelo Estado.

A nacionalização do gás e petróleo anunciada pela Bolívia, em $1^{\circ}$ de maio de 2006, poderia ter-se concentrado em elementos específicos que poderiam tê-la

2 Para a Lei de Hidrocarbonetos n. 1.689 , de 30 de abril de 1996, art. $1^{\circ}$, $\$ 1^{\circ}$, contratos de risco compartilhado, no contexto de contratos de concessão, deviam ser celebrados para a prospecção, exploração e comercialização do gás e petrólco.

3 A expressão "government take", neste texto, quer dizer basicamente a parcela da renda das empresas privadas envolvidas na prospeção. exploração e comercialização de hidrocarbonclos que ć apropriada pelo Estado mediante impostos e royalties. 
legitimado tanto interna como externamente. Primeiro, poderiam ter sido recuperadas jazidas que não tivessem sido perfuradas ao teor do previsto em contratos. Segundo, poderiam ter sido revistos ou rescindidos contratos com empresas estrangeiras que não tivessem cumprido seus compromissos de investimento. Em ambos os casos, haveria o descumprimento de cláusulas contratuais da parte de empresas estrangeiras.

A estratégia adotada pela Bolívia foi diferente. As jazidas de gás e petróleo, como já tivemos a oportunidade de salientar anteriormente, já pertenciam ao Estado. Não se considera suficiente rever ou rescindir contratos de risco compartilhado com empresas estrangeiras. A Yacimientos Petrolíferos Fiscales Bolivianos (YPFB), a empresa estatal boliviana do gás e petróleo, é uma empresa descapitalizada, sem condições de financiar suas atividades e sem quadros para garantir sozinha a continuidade da produção. ${ }^{4}$ A meta do governo era capitalizar a YPFB para que ela passasse a centralizar da maneira mais abrangente possível a prospecção, exploração e comercialização de hidrocarbonetos. Para capitalizar a YPFB, seria necessário descapitalizar as empresas estrangeiras presentes na Bolívia, expropriando-as.

O Estado boliviano já se apropriara crescentemente nos últimos anos da renda auferida pelas empresas estrangeiras com a prospecção, exploração e comercialização de hidrocarbonctos. A nova Lei de Hidrocarbonetos n. 3.058, de 17 de maio de 2005 , elevara o government take de $18 \%$ para $50 \% .^{5}$ A partir de $1^{\circ}$ de maio de 2006, a porcentagem de apropriação da renda por parte do Estado, ao menos nos campos mais produtivos, como os da Petrobras, aumentou para $82 \% .{ }^{6} \mathrm{~A}$ Petrobras instalou-se na Bolívia a partir de 1996 no bojo de um acordo celebrado entre os governos do Brasil e da Bolívia. Este acordo possibilitou a prospecção, exploração e comercialização das reservas de gás natural bolivianas.

A expropriação das empresas estrangeiras tem como pressuposto dotar a YPFB de capital que the assegure poder investir continuamente na prospecção. exploração e comercialização de hidrocarbonetos, com ou sem a participação de empresas estrangeiras. Se este processo de capitalização da YPFB à custa da descapitalização das empresas estrangeiras não for bem-sucedido, os indicadores de produção de gás e petróleo na Bolívia começarão a declinar. prejudicando a atividade econômica. A elevação do government tuke de 18\% para $82 \%$ atesta que o Estado boliviano tem precisado apropriar-se de porcentagens de renda cada vez mais altas, que desencorajam o investimento estrangeiro, para injetar recursos na YPFB com o objetivo de assegurar-lhe meios para assumir o "controle absoluto" dos hidrocarbonetos. A

A YPFB foi criada em 21 de dezembro de 1936. durante o govemo do coronel David Toro.

Lei de Hidrocarbonetos n. 3.058, de 17 de maio de 2005 , art. $55, \S 3^{\circ}$

Decreto Supremo n. 28.701 , de $1^{\circ}$ de maio de 2006, art. $4^{\circ}$, inciso I. 
Bolivia possui uma longa história pendular no que diz respeito à nacionalização do gás e petróleo.

2. Modelos históricos de nacionalização do gás e petróleo

Há basicamente três modelos extremos de apropriação da renda auferida com a prospecção, exploração e comercialização de hidrocarbonetos. Primeiro, o Estado monopoliza a atividade e apropria-se da renda mediante uma empresa estatal. Segundo, o Estado compartilha a atividade entre uma empresa estatal e empresas privadas, apropriando-se de parte da renda destas últimas através de impostos e royalties. Terceiro, o Estado também se apropria de parte da renda auferida com a prospecção, exploração e comercialização de hidrocarbonetos através de impostos e royalties que são pagos por empresas privadas, mas há uma diferença com relação ao segundo modelo. A atividade não é compartilhada entre uma empresa estatal e empresas privadas. Só há, no terceiro modelo, empresas privadas explorando o setor. No primeiro modelo, encaixam-se. por exemplo, a Arábia Saudita e o Irã. No segundo, até recentemente ao menos, a Bolívia. Quanto ao terceiro modelo, podemos dar o exemplo dos Estados LInidos, que nunca tiveram uma empresa estatal do petróleo.?

Nacionalizar pode significar reverter direitos de propriedade em benefício do Estado e outorgar, como compensação, uma indenização às empresas expropriadas. $\mathrm{O}$ Estado tem o domínio eminente sobre as pessoas no âmbito de seu território e, indiretamente, sobre a propriedade destas últimas. Argüindo utilidade pública, o Estado pode nacionalizar uma atividade que anteriormente era possuida, controlada e administrada pela iniciativa privada. Autoridades públicas tradicionalmente desapropriam propriedade privada para, por exemplo, a construção de estradas, represas. prédios públicos etc. O conceito de "nacionalização" no entanto, desenvolveu-se sobretudo durante o século XX, diferenciando-se consideravelmente do de "desapropriação" Nacionalizar implicaria expropriar com o propósito de assegurar justiça e igualdade, tanto sob o ponto de vista social como econômico. entre os variados países que fazem parte da comunidade internacional. Os antigos paises comunistas da Europa Oriental nacionalizaram praticamente toda a indústria e agricultura no periodo que se seguiu à Segunda Guerra Mundial. Durante o governo trabalhista de 1945-1951, o Reino Unido nacionalizou uma quantidade importante de setores. incluindo o do carvão.

O Brasil, com a Petrobras como empresa estatal, passou há pouco tempo de um monopólio total em que a Petrobras cra um agente excludente para um em que se passou a aceitar a coexistência de empresas privadas na prospecção, exploração e comurcialização de hidrocarbonetos. O Brasil. então, abandonou o primeiro modelo para adotar em seguida o segundo modelo. 
Em paises não-comunistas, tornou-se praxe indenizar os proprietários do que era expropriado. Nos antigos países comunistas, onde a propriedade privada dos meios de produção, como princípio, não era aceita, a indenização não costumava ser concedida. ${ }^{8}$

A expropriação de empresas estrangeiras costuma ocorrer sobretudo em países em desenvolvimento, nos quais há um ressentimento com relação à internacionalização de setores-chave da economia. O México nacionalizou, em 1938, o setor petrolifero controlado por empresas americanas. O Irã expropriou, em 1951, a Anglo-Iranian Oil Company, e o Egito, em 1956, a Suez Canal Company. O Chile expropriou. em 1971. a indústria de mineração de cobre controlada por empresas estrangeiras. Tais expropriações dão ensejo a questões complexas sob o ponto de vista do Direito Internacional Público. Em alguns casos, o problema é resolvido com as partes expropriadas obtendo indenização. Em outros casos. quando não há indenização, pode haver uma debilitação nas relações internacionais entre os países envolvidos. Alguns paises em desenvolvimento sustentam que a concessão outorgada por um país a uma empresa estrangeira não é um acordo internacional, estando sujeita ao direito nacional do Estado concedente. As empresas estrangeiras teriam, assim, de assumir os riscos da expropriação.

A Bolivia já adotou anteriormente por duas vezes a nacionalização do gás e petróleo, com a expropriação de empresas estrangeiras. A primeira vez foi em 1937, durante o Governo do coronel David Toro. A segunda vez ocorreu em 1969, quando o país era governado pelo general Alfredo Ovando. A primeira nacionalização teria tido uma motivação revanchista. A Standard Oil teria atentado contra os interesses bolivianos durante a Guerra do Chaco, na qual a Bolivia perdeu parte de seu território para o Paraguai. ${ }^{9}$ Ela teria resistido a vender gasolina ao Exército boliviano, bem como teria exportado petróleo clandestinamente à Argentina e ao Paraguai. Suspeitas como estas, e de evasão de impostos, teriam levado à sua expropriação em 13 de março de 1937. seguida do pagamento de uma indenização. Fsta foi a primeira nacionalização que a Standard Oil sofreu, então a empresa petrolífera mais importante do mundo. A nacionalização contribuiu para que o mercado financeiro internacional se tornasse refractário à Bolivia. A YPFB, a estatal boliviana de hidrocarbonetos, não dispôs, no entanto, de recursos para investir com o objetivo de aumentar a produção de gás e petróleo. A segunda expropriação de empresas estrangeiras ocorreu no contexto do

s Num sentido mais amplo. "nacionalizar" significa a açào de conventer uma coisa estrangeira em coisa nacional. "Nacionalizaçào" adquire entào um scntido econòmico e social que pode emprestar-lhe um novo significado: é a política de Estado que exclui empresas cstrangeiras de setores cconômicos especificos.

- A Guerra do Chaco é conhecida na Bolivia como a "Guerra do Petróleo". Suspeitava-se que no Chaco, regıão proxima ao Mato Grosso do Sul. houvesse jazidas de petróleo, suspeita que mais tarde se revelou infundada. 
Código do Petróleo, de 1956, que pretendera criar condições para atrair investimento. Ele contribuiu para trazer ao pais muitas empresas estrangeiras. A com mais sucesso teria sido a Gulf Oil Company. Em 1968, o general René Barrientos suspendeu a vigência do Código do Petróleo. Surgiram condições para que o general Alfredo Ovando expropriasse posteriormente a Gulf Oil Company, novamente seguida do pagamento de uma indenização. A YPFB e o Governo boliviano beneficiaram-se desta iniciativa num primeiro momento. Com a expropriação de 17 de outubro de 1969, o mercado financeiro tornou-se novamente refractário à Bolívia. A "recuperação completa" do gás e petróleo teve sucesso inicialmente devido ao aumento do preço dos hidrocarbonetos. A partir de 1973, com o primeiro choque do petróleo, seu preço elevou-se, aumentando a fonte de renda com exportações da Bolivia.

Não há consenso sobre o que a Bolívia alcançou efetivamente sob o ponto de vista econômico com as expropriações de 1937 e 1969. O resultado teria sido a postergação por décadas do desenvolvimento, crescimento e expansão da indústria petrolífera boliviana. Já em começos dos anos 70, sustentava-se que era necessário industrializar localmente, em território boliviano, o gás natural. Mas a YPFB não teve como dar seguimento a este projeto. Hoje, não há garantias de que a YPFB poderá industrializar o gás natural na Bolívia. Não somente pela falta de recursos. A "recuperação completa" do gás e petróleo pode ser um pretexto para o aumento da estrutura burocrática da YPFB.

As principais entidades que apoiaram a última expropriação de empresas estrangeiras, ocorrida em $1^{\circ}$ de maio de 2006, foram a Central Operária Boliviana $(\mathrm{COB})^{10}$ e o Comitê de Defesa do Patrimônio Nacional (Codepanal)." O modelo de nacionalização adotado continuou a ser o que compreende o compartilhamento da atividade de prospeç̧ão, exploração e comercialização de hidrocarbonetos entre uma empresa estatal e empresas privadas, apropriando-se o Estado de parte da renda auferida por estas últimas através de impostos e royalties. Mas o government take, a parcela da renda a ser apropriada pelo Estado boliviano, passaria a ser muito maior. A "adequação" do sistema de impostos e royalties proposta pela $\mathrm{COB}$ e pelo Condepanal compreendia aumentar o government lake em até no mínimo $50 \%{ }^{12}$

A Bolívia conduziu na data assinalada no parágrafo anterior a ocupação militar das refinarias que eram operadas sobretudo pela Petrobras. Ela, a Petrobras, não

10 Central Obrera Boliviana (COB).

11 Comité de Defensa del Patrimonio Nacional (Codepanal).

12 Conforme já tivemos a oportunidade de salientar anteriormente, a partir de $1^{\circ}$ de maio de 2006 o government take passou a alcançar até $82 \%$, bem acima do que fora proposto inicialmente pela C.OB e pelo Codepanal. 
teve oportunidade para assimilar o decreto de expropriação. Ocupou-se primeiramente manu militare os campos para, depois, negociar-se durante 180 dias novos contratos com as empresas estrangeiras. ${ }^{13} \mathrm{~A}$ imagem de soldados ocupando jazidas e refinarias pode ter prejudicado em muito aquele país. À maneira do que ocorreu no passado, a Bolívia adotou tais medidas estimulada pelo aumento do preço do gás e petróleo no mercado internacional. É na Região Andina que cresce o consenso acerca da "recuperação completa" dos hidrocarbonetos como uma forma de incrementar as rendas do Estado. ${ }^{14} \mathrm{O}$ Brasil é um dos maiores investidores no setor energético boliviano e seu principal comprador de gás natural. Foi o país mais prejudicado com as medidas adotadas em $1^{\circ}$ de maio de 2006. A Petrobras foi uma das poucas empresas estrangeiras a sentir o impacto da decisão boliviana, além da espanhola Repsol e da francesa Total.

A ocupação militar de refinarias ocorrida em $1^{\circ}$ de maio de 2006 não é um fenômeno isolado na história recente da Bolívia. Faz parte de um contexto social mais amplo. O sistema de abastecimento de água na Bolívia foi desprivatizado a partir de levantes populares, ocorridos em abril de 2000, na cidade de Cochabamba, conhecidos como a "Guerra da Água" Posteriormente, em outubro de 2003, a Bolívia foi convulsionada novamente por outro levante popular, a "Guerra do Gás" com a participação de organizações sociais, políticas, sindicais, cívicas e de vizinhança, em que se exigia a "recuperação completa" dos hidrocarbonetos. As táticas de mobilização abrangeram marchas, bloqueios de estradas, sitiamento de povoados e cidades. Em 17 de outubro de 2003, o então presidente Gonzalo Sánchez de Lozada, que não apoiava a "recuperação completa" dos hidrocarbonetos, com a apropriação maciça da renda das empresas estrangeiras através do aumento de impostos e royalties, renunciou em benefício de seu vice-presidente, Carlos Mesa. ${ }^{15}$

3. Mecanismos jurídicos para a nacionalização do gás e petróleo

Diferentes mecanismos jurídicos podem ser utilizados para a nacionalização do gás e petróleo. Várias alternativas foram analisadas pelo Governo boliviano antes de $1^{\circ}$ de maio de 2006. Vamos, em seguida, discorrer brevemente sobre

Decreto Supremo n. 28.701 , de $1^{\circ}$ de maio de 2006 , art. $3^{\circ}$, inciso I.

it No Equador e na Venezuela, adotaram-se recentemente medidas que aumentam a participação do Estado nos ganhos com a exportação do petróleo.

" Com a "rucuperação completa" dos hidrocarbonetos, o governo boliviano pretenderia resolver us problemas econòmicos e sociais do pais. A criação de um novo modelo de desenvolvimento econômico só seria possivel se se atendesse de maneira integral as necessidades de todos us bolivianos. o que só seria possivel se o Estado detivesse o "controle absoluto" de seus recursos. 
os principais mecanismos jurídicos que foram cogitados para colocar em prática a "recuperação completa" dos hidrocarbonetos.

A primeira alternativa cogitada foi a da expropriação por razão de utilidade pública. Embora tendo sido considerada procedente sob o ponto de vista jurídico, não foi considerada conveniente sob o ponto de vista político. A expropriação por razão de utilidade pública implicaria a necessidade de pagamento de indenização, determinada pelo dano emergente e pelo lucro cessante da empresa expropriada. Este mecanismo jurídico foi considerado inicialmente como sendo demasiadamente complexo e custoso para a Bolivia. Seria necessário pensar-se num mecanismo jurídico de "recupcração completa" dos hidrocarbonetos que implicasse o menor montante possível de indenização. O caminho a ser percorrido para a "recuperação completa" dos hidrocarbonetos deveria, então, circunscrever-se aos mecanismos jurídicos previstos no Direito boliviano em matéria de contratos. Transferindo-se às empresas estrangeiras 0 ônus do descumprimento de cláusulas contratuais, a "fé do Estado" não seria afetada. A Bolívia seria assim liberada da melhor forma viável da indenização às empresas estrangeiras, reconhecendo-se apenas a compensação pelos investimentos realizados no país após a realização de auditoria. ${ }^{10}$

A segunda alternativa vislumbrada pelo Governo boliviano passou a ser a da resolução ou cessação de contratos. O primeiro passo seria a realização de uma auditoria jurídica e financeira para estabelecer a validez e/ou cumprimento das cláusulas contratuais. Ela precisaria o montante de investimento previsto nas cláusulas contratuais e o montante de investimento colocado em prática de fato pelas empresas estrangeiras para a exccução dos projetos de prospeç̧ão, exploração e comercialização de gás e petróleo. A maioria das empresas não teria realizado os investimentos previstos em cláusulas contratuais. Caberia, então, processar as empresas estrangciras mediante uma ação de resolução ou cessação de contratos. ${ }^{17}$ Não-só se argumentava que turia ocorrido a não-execução do montante de investimento previsto contratualmente, como que as empresas estrangeiras teriam efetuado a manipulação de documentos contábeis e dados

16 Para a expropriação das empresas estrangeiras, terminou-se, no entanto, confiscando $51 \%$ de suas ações, de modo que o Estado participasse de suas decisões, negócios e lucros (Decreto Supremo n. 28.701, de $1^{\text {" }}$ de maio de 2006 , art. $7^{\circ}$, inciso II). Esta altemativa foi considerada menos drástica do que o confisco de $100 \%$ das ações, sobretudo devido ao possível impacto proveniente da indenização.

17 Código Civil boliviano, art. 568: "I. En los contratos con prestaciones reciprocas cuando una de las partes incumple por su voluntad la obligación, la parte que ha cumplido puede pedir judicialmente el cumplimiento o la resolución del contrato. más el resarcimiento del daño: o también puede pedir sólo el cumplimiento dentro de un plazo razonable que fijará el juez, y no haciéndose electiva la prestación dentro de ese plazo quedará resuelio el contrato, sin perjuicio, en todo caso, de resarcir el daño. (Arts. 344. 520, 596 del Código Civil). II. Si se hubiera demandado solamente la resolución. no podra ya pedirse el cumplimiento del contrato: y el demandado, a su vez, ya no podrá cumplir su obligación desdc' el dia de su notificación con la demanda" 
de produção e comercialização, fraudando o Estado. A própria Corte Suprema de Justiça $^{18}$ seria competente para julgar a ação relativa à resolução ou cessação de contratos, à luz do previsto no art. 775 do Código de Processo Civil boliviano (") e no art. 118 , inciso $\mathrm{I}, \S 7^{\circ}$, da Constituição boliviana ${ }^{20}$. Os contratos para a prospecção. exploração e comercialização de gás e petróleo haviam sido celebrados à luz da Lei de Hidrocarbonetos n. 1.689 , de 30 de abril de 1996. Seu art. $30, \S 1^{\circ}$ previa que as empresas estrangeiras deviam perfurar um poço de petróleo em cada parcela que thes fosse concedida. As empresas que detivessem entre 4 a 6 parcelas, teriam a obrigação de perfurar entre 4 a 6 poços. Algumas teriam perfurado um máximo de 2 poços. Se, após cinco anos de outorgada a concessão, as empresas estrangeiras não tivessem construído a quantidade de poços estipulados, as parcelas reverteriam automaticamente ao Estado. ${ }^{21}$

Como terceira alternativa, aventou-se a anulação de contratos. ${ }^{2:}$ Seu objetivo seria invalidar os contratos celebrados com empresas estrangeiras para a prospeç̧ão, exploração e comercialização de hidrocarbonetos, bem como seus efeitos jurídicos. A respectiva ação seria julgada procedente, quando cláusulas contratuais colidissem com preceitos constitucionais. Os contratos transfeririam de facto a propriedade do gás e petróleo a empresas estrangeiras, contradizendo o previsto na Constituição boliviana, art. 139. ${ }^{23}$ Outro caso de colisão de cláusulas contratuais com preceitos constitucionais diria respeito ao fato de os contratos contemplarem a solução

i. A Corte Suprema de Justiça é o órgâo máximo do Poder Judíciário boliviano.

19 Código de Processo Civil boliviano, art. 775: "En todos los casos en que existiere contención emergente di los contratos, negociaciones o concesiones del Poder Ejecutivo, conforme a las previsiones perinentes de la Constitución Politica del Estado, se presentará la demanda ante la Corte Suprema de Justicia con los requisitos señalados en el articulo 327"

20 Constituição boliviana. art. 118. inciso I: "Son atribuciones de la Corte Suprema: 7" Conocer y resolver causas y recursos en materia contencioso-administrativa, conforme a ley"

21 Lei de Hidrocarbonetos n. 1.689, de 30 de abril de 1996, art. 30, \$1: "El área de explolación seleccionada dentro del área del contrato por cada descubrimiento comercial, tendrá una superficie maxima de diez parcelas. En cualquier caso, si en el plazo de cinco años desde la notificación a YPFB y a la Secretaria Nacional de Energía con la declaratoria de un descubrimiento comercial, el interesado no hubiese efectuado la perforación de al menos un pozo productor o de inyección en cada una de las parcelas seleccionadas, éstas serän obligatoriamente devueltas"

22 Código Civil boliviano, art. 549: "El contrato será mulo: 1) Por faltar en el contrato, el objeto o la furma prevista por la ley como requisito de validez. 2) Por faltar en el objeto del contrato los requisitos señalados por la ley. 3) Por ilicitud de la causa y por ilicind del motivo que impulsó a las partes o celebrur el contrato. 4) Por error esencial sobre la naturaleza o sobre el objeto del contrato. 5) En los demás casos determinados por la ley"

23 Constituição boliviana, art. 139: "Los yacimientos de hidrocarburos. cualquiera que sea el estado en que se encuentren o la forma en que se presenten. son del dominio directo. inalienable e impriscriptible del Estado. Ninguna concesión o contrato podrá conferir la propiedad de los yacimientos de hidrocarhurns. La exploración. explotación. comercialización y transporte de los hidrocarburos y sus derivadus. corresponden al Estado. Este derecho lo ejercerá mediante entidad's autärquicas o a travís dt' concesiones y contratus por tiempo limitado, a suitedudes mixtas de operación conjumta o a personas privadas, conforme a ley" 
de controvérsias em tribunais do exterior, infringindo o art. 135 da Constituição boliviana: "Todas as empresas estabelecidas para explorações, aproveitamento ou negócius no país considerar-se-ão nacionais e estarão submetidas à soberania, às leis e às autoridades da República" ${ }^{24}$ Também teria havido nulidade por vício de forma. Os contratos celebrados com empresas estrangeiras para a prospecção, exploração e comercialização de hidrocarbonetos não teriam sido submetidos à aprovação do Poder Legislativo, violando o art. $59, \S 5^{\circ}$, da Constituição boliviana. ${ }^{25} \mathrm{~A}$ ação de anulação de contratos é imprescritível. ${ }^{26}$

\section{Constituição boliviana}

A Constituição boliviana assegura de longa data que o Estado é o proprictário de suas jazidas de gás e petróleo de maneira direta, inalienável e imprescritível. O gás natural e o petróleo não foram nacionalizados em $1^{\circ}$ de maio de 2006. O que houve foi a expropriação das empresas estrangeiras envolvidas na prospecção, exploração e comercialização do gás e petróleo.

A Parte Terceira da Constituição boliviana intitula-se "Regimes Especiais" ${ }^{27}$ Seu Título Primeiro diz respeito ao "Regime Econômico e Financeiro" 28 Divide-se, o Título Primeiro, entre outros, em Capítulo I, referente a "Disposições Gerais", ${ }^{29}$ e o Capitulo Il, a "Bens Nacionais" $30 / 31$

$\mathrm{O}$ art. 133 da Constituição boliviana determina qual é a "finalidade do regime econômico" do país: "O regime econômico favorecerá o fortalecimento da independência nacional e o desenvolvimento do país mediante a defesa e o aproveitamento dos recursos naturais e humanos no resguardo da segurança do Estado e à procura do bem-estar do povo boliviano" ${ }^{2}$ Proíbe-se, no art. 134, a acumulação

24 Constituição boliviana. art. 135: "Todas las empresas establecidas para explotaciones. aprovechamientoo negocios en el pais se considerarán nacionales y estarán sometidas a la soberania, a las leves y a las autoridades de la Republica"

25 Constituição boliviana, art. 59: "Son atribuciones del Poder Le'gislativo (...) $\$ 5^{\circ}$ : Autorizar y aprobar la contratación de empréstitos que comprometan las rentas generales del Estado. asi como los contratos relativos a la explotación de las riquezas nacionales"

26 Código Civil boliviano, an. 552: "La accción de nulidad es imprescriptible"

27 Constituição boliviana, Parte Terceira: "Regimenes Especiales"

28 Constituição boliviana, Parte Terccira. Título Primeiro: "Regimen Ecomómico y Financiero"

29 Constituição boliviana. Parte 'lerceira. Título Primeiro, Capitulo I: "Disposiciones Generales"

30 Constituição boliviana, Parte Terceira, Título Primeiro. Capítulo II: "Bienes Nacionales"

${ }^{31}$ O Capitulo I e o Capítulo II compreendem os arts. 132-140.

32 Constituiçào boliviana, art. 133: "El régimen económico propenderá al fortalecimiento de la independencia nacional y al desarrollo del pais mediante la defensa y el aprovechamiento de los ricursos naturales y humanos en resguardo de la seguridad del Estado y en procura del bienestar del pueblo boliviano" 
privada de poder econômico e o monopólio: 'Não se permitirá a acumulação privada de poder econômico num tal grau que ponha em perigo a independência econômica do Estado. Não se reconhece nenhuma forma de monopólio privado. As concessões de serviços públicos, quando forem feitas excepcionalmente, não poderão ser outorgadas por um período maior do que quarenta anos" 33

$\mathrm{O}$ art. 136 prevê que os bens nacionais são do domínio originário do Estado: "I. São de domínio originário do Estado, além dos bens aos quais a lei lhes dê essa qualidade, o solo e o subsolo com todas suas riquezas naturais, as águas lacustres, fluviais e medicinais, assim como os elementos e forças físicas susceptiveis de aproveitamento. II. A lei estabelecerá as condições deste domínio, assim como as de sua concessão e adjudicação aos particulares" ${ }^{\imath 4}$ Os bens nacionais, à luz do art. 137 , constituem propriedade pública: "Os bens do patrimônio da Nação constituem propriedade pública, inviolável, sendo dever de todo habitante do território nacional respeitá-la e protegê-la" ${ }^{35} \mathrm{O}$ art. 139 determina que o Estado boliviano é o proprietário de suas jazidas de gás e petróleo de maneira direta, inalienável e imprescritível: "As jazidas de hidrocarbonetos, qualquer que seja o estado em que se encontrem ou a forma em que se apresentem, são do domínio direto, inalienável e imprescritível do Estado. Nenhuma concessão ou contrato poderá conferir a propriedade das jazidas de hidrocarbonetos. A prospecção, exploração, comercialização e transporte dos hidrocarbonetos e seus derivados correspondem ao Estado. Este direito será exercido mediante entidades autárquicas ou através de concessões e contratos por tempo limitado, a sociedades mistas de operação conjunta ou a pessoas privadas, conforme a lei" ${ }^{36}$

Ao aumentar o government take mediante a "adequação" do sistema de impostos e royalties, a Bolívia, a partir de $1^{\circ}$ de maio de 2006 , expropriou a renda

33 Constituição boliviana, art. 134: "No se permitirá la acumulación privada de poder económico en grado tal que ponga en peligro la independencia economica del Estado. No se reconoce ninguna forma de monopolio privado. Las concesiones de servicios públicos, cuando excepcionalmente se hagan, no podran ser otorgadas por un periodo mayor de cuarenta años"

34 Constituição boliviana, art. 136: "I. Son de duminio originario del Estado, además de los bienes a los que la ley les da esa calidad, el suelo y el subsuelo con todas sus riquezas naturales, las aguas lacustres, fluviales y medicinales. asi como los elementos y fuerzas fisicas susceptibles de aprovechamiento. II. La ley establecerá las condiciones de este dominio. asi como las de su concesión y adjudicación a los particulares".

35 Constituição boliviana, ant. 137: "Los bienes del patrimonio de la Nación constituyen propiedad publica. inviolable, siendo deber de todo habitante del territorio nacional respetarla y protegerla"

36 Constituição boliviana, art. 139: "Los yacimientos de hidrocarburos, cualquiera que sea el estado en que se encuentren o la forma en que se presenten. son del dominio directo, inalienable e imprescriptible del Estado. Vinguna concesión o contrato podrá conferir la propiedad de los yacimientos de hidrocarburos. La exploración. explotación. comercialización y transporte de los hidrocarburos y sus derivados. corresponden al Estado. Este derecho lo ejercerá mediante entidades autárquicas o a través de concesiones y contratos por tiempo limitado. a sociedades mixtas de operación coniunta o a personas privadas, conforme a ley" 
auferida pelas empresas estrangeiras com a prospecção, exploração e comercialização do gás e petróleo, o que pode ser um indício de que elas, à semelhança dos grupos de mineração, venham a ter no futuro sua propriedade completamente transferida ao governo. A Constituição boliviana, art. 138, a propósito, prevê que a mineração nacionalizada é patrimônio da Nação: "Pertencem ao patrimônio da Nação os grupos de mineração nacionalizados como uma das bases para o desenvolvimento e diversificação da economia do pais, não podendo aqueles serem transferidos ou adjudicados em propriedade a empresas privadas a nenhum título. A direção e administração superiores da indústria de mineração estatal estarão a cargo de uma entidade autárquica com as atribuições que determina a lei" ${ }^{37}$

5. Referendo sobre os hidrocarbonetos

Em outubro de 2003. a Bolívia atravessou uma séria crise política, a chamada "Guerra do Gás" Protestos sociais paralisaram o país. provocando várias dezenas de mortos e feridos. Organizações camponesas e operárias formaram uma frente contra o ex-presidente Gonzalo Sánchez de Lozada, pedindo sua renúncia. Exigia-se a convocação de uma assembléia constituinte, a realização de um referendo sobre a "recuperação completa" dos hidrocarbonetos e a não-exportação de gás natural ao Chile. $^{38}$ Em 17 de outubro de 2003. o ex-presidente Gonzalo Sánchez de Lozada renunciou. O então vice-presidente Carlos Mesa assumiu o Governo, tendo sido aceito pelo Congresso boliviano como sucessor constitucional.

Carlos Mesa convocou então um referendo que desde o início foi paradoxalmente considerado como tendo uma natureza antidemocrática pelas organizações camponesas e operárias. Seu objetivo não teria sido o de atender os anseios de grandes setores da população boliviana, mas o de legitimar a aplicação de uma nova lei de hidrocarbonetos ${ }^{39}$ que não diferiria em nada da lei de hidrocarbonetos em vigor. ${ }^{40}$

Constituição boliviana. ant. 138: "Pertenecen al patrimonio de la Nación los grupos mineros nacionalizados como una de las bases para el desarrollo y diversificación de la economia del pais. no pudiendo aquéllos ser transferidos o adjudicados en propiedad a empresas privadas por ningín título. La dirección y administración superiores de la industria minero estatal estaran a cargo de una entidad autárquica con las atribuciones que determina la ley"

$38 \mathrm{Na}$ Guerra do Pacifico, travada entre 1879 e 1883 , o Chile venceu a aliança formada por Bolivia e Peru. Os bolivianos perderam seu acesso ao mar. Isto provocou um forte ressentimento popular na Bolívia até hoje, levando sua população a rejeitar, por exemplo, a exportaçâo de gás natural ao Chile.

39 A nova lei de hidrocarbonetos terminou sendo aprovada em 17 de maio de 2005, nos estertores do Governo Carlos Mesa. Intitulou-se Lei de Hidrocarbonetos n. 3.058, de 17 de maio de 2005.

to A lei de hidrocarbonetos então em vigor contra a qual se insurgira a populaçàn boliviana era a Lei de Hidrocarbonetos n. 1.689. de 30 de abril de 1996. Ela fora aprovada durante o Guverno de Gonzalo Sánchez de Lozada. sendo considerada favorável aos interesses das empresas estrangciras. 
O resultado do referendo seria indiferente. Terminaria legitimando a política anterior de Gonzalo Sánchez de Lozada com relação aos hidrocarbonetos, favorável às empresas estrangeiras. As demandas populares, do levante de outubro de 2003, compreendiam basicamente o seguinte: a "recuperação completa" dos hidrocarbonetos; o fortalecimunto da YPFB como empresa estatal que participasse de todo o processo de prospecção, exploração e comercialização de hidrocarbonetos; e a elevação do government tuke em até no mínimo $50 \%{ }^{41}$ Carlos Mesa era acusado de utilizar o referendo para legitimar as empresas estrangeiras que celebraram contratos com o governo boliviano para a compra e venda de gás e petróleo. ${ }^{42}$

O ex-presidente Carlos Mesa seguiu adiante, indo ao encontro das exigências das organizações camponesas e operárias. prometendo: I) estabelecer uma assembléia constituinte; 2) convocar um referendo vinculante sobre o gás natural; e 3) reformular a Lei de Hidrocarbonetos n. 1.689, de 30 de abril de 1996, então em vigor." A Constituição boliviana. art. $4^{\circ}$, inciso I. prevê: "O povo delibera e governa por meio de seus representantes e mediante a iniciativa legislativa cidadã e o referendo constitucional, estabelecidos por esta Constituição e normatizados por lei" ${ }^{44}$ Gonzalo Sánchez de Lozada pretendera realizar um referendo consultivo para decidir o destino dos hidrocarbonetos. Carlos Mesa, ao contrário, comprometeu-se a realizar um referendo vinculante. Os resultados do referendo determinariam sua política com relação ao gás e petróleo. ${ }^{45} \mathrm{O}$ presidente Carlos Mesa convocou o referendo vinculante para 18 de julho de 2004, mas não submeteu à apreciação popular o Projeto de Lei de Hidrocarbonetos

41 Também se pretendia, como já tivemos a oportunidade de salientar. proibir a exportação do gás ao Chile e industrializar os hidrocarbonetos em território boliviano.

42 Se ganhasse o "sim", o povo legitimaria a nova Lei de Hidrocarbonetos proposta por Carlos Mesa, que aprofundaria o paradigma da antiga Lei de Hidrocarbonetos, que não contemplava sua "recuperaçào completa". Se o povo votasse pelo "não", ele legitimaria a antiga Lei de Hidrocarbonetos. As perguntas do referendo circunscreveriam a decisão do povo entre estas duas opções que seriam ao fim e ao cabo exatamente iguais.

13 O ex-presidente Carlos Mesa teve de enfrentar uma coalizão dos comitês civicos dos departamentos de Santa Cruz, Beni, Pando e Tarija. Santa Cruz, Beni e Pando são departamentos, "provincias". situadas na região leste da Bolívia. junto ao Brasil. Estes très departamentos são o celeiro da Bolívia, com terras férteis e bem cultivadas. Tarija. um departamento na região sul da Bolívia, junto à Argentina, tem as maiores jazidas de gás da Bolivia. Hisıoricamente, Santa Cruz, Beni, Pando e Tarija têm demandado mais descentralização e autonomia com relação ao governo central de La Paz. Em casos extremos, sua própria independincia.

4 Constituição boliviana, art. $4^{\circ}$, inciso I: "El pueblo delibera y gobierna por medio de sus representantes y mediante la iniciativa Legislativa Ciudadana y el Referéndum Constitucional, establecidos por esta Constitucion y normados por ley"

4. Os membros do Comitê Civico de Tarija argumentaram que $85 \%$ das reservas de gás e petróleo se encontram nistc departamento, o qual tem um colégio eleitoral pequeno, com apenas $4,85 \%$ do total. A decisão sobre o que fazer com o gás e petróleo terminou ficando a cargo dos departamentos consumidores de hidrocarbonetos, contrários à exportação de gás não industrializado, e não dos departamentos produtores. 
apresentado ao Congresso Nacional. ${ }^{46}$ A Central Operária Boliviana (COB) manifestouse contra o referendo, já que suas perguntas não contemplavam a "recuperação completa" dos hidrocarbonetos. Carlos Mesa não era a favor da expropriação das empresas estrangeiras. ${ }^{47}$

As cinco perguntas, do referendo de 18 de julho de 2004, foram as seguintes: $:^{48}$

1. Você está de acordo com a ab-rogação da Lei de Hidrocarbonetos n. 1.689 promulgada por Gonzalo Sánchez de Lozada? Sim ou não." ${ }^{\$ 9}$

2. Você está de acordo com a recuperação da propriedade de todos os hidrocarbonetos em boca de poço ${ }^{50}$ para o Estado boliviano? ${ }^{51}$

3. Você está de acordo com a refundação da Yacimientos Petroliferos Fiscales Bolivianos, recuperando a propriedade estatal das ações das bolivianas e dos bolivianos nas empresas petroliferas capitalizadas. de maneira que possa participar em toda a cadeia produtiva dos hidrocarbonetos? $?^{52}$

4. Você está de acordo com a politica do presidente Carlos Mesa de utilizar o gás como recurso estratégico para conseguir uma saida útil e soberana ao Oceano Pacífico??

5. Você está de acordo com que a Bolívia exporte gás no marco de uma política nacional que cubra o consumo de gás das bolivianas e dos bolivianos, fomente a industrialização do gás no território nacional, cobre impostos e/ou royalties às empresas petrolíferas chegando a $50 \%$ do valor da produção do gás e do

to Segmentos sociais argumentaram que o referendo era inconstitucional. O referendo necessitaria de uma lei especifica que o autorizasse. Ele foi convucado mediante decreto presidencial.

47. O Movimento ao Socialismo (MAS), do atual presidente Evo Morales, realizou uma propaganda a favor do "sim" para as três primeiras perguntas do referendo e do "nào" para as duas restantes.

48 Três argumentus foram utilizados sob o ponto de vista técnico e jurídico contra o referendo: falta de legalidade, falta de consistência em cada pergunta e complexidade da linguagem e das perguntas.

49 Referendo de 18 de julho de 2004, pergunta n. 1: "¿Está usted de acuerdo con la abrogación de la Ley de Hidrocarburos 1689 promulgada por Gonzalo Sánchez de Lozada? Si o №"

so "Boca de Pozo: Es el punto de salida de la corriente tolal de fluidos que produce un pozo (Petróleo, Gas Natural. Agua de Formación y Sedimentos), untes de ser conducidos a un Sistema de Adecuación" (Lei de Hidrocarbonetos n. 3.058, de 17 de main de 2005. art. 138).

51 Referendo de 18 de julho de 2004, pergunta n. 2: “¿Esia usted de acuerdo con la recuperación de la propiedad de lodos los hidrocarburos en boca de pozo para el Estado boliviano?"

52 Referendo de 18 de jultho de 2004, pergunta n. 3: “¿Está usted de acuerdo con refundar Yacimientos Petroliferos Fiscales Bolivianos, recuperando la propiedad estatal de las acciones de las bolivianas y los bolivianos en las empresas petroleras capitalizadas, de manera que pueda participar en toda la cadena productiva de los hidrocarburos?"."

53 Referendo de 18 de julho de 2004, pergunta n. 4: "¿Está usted de acuerdo con la politica del president." Carlos Mesa de utilizar el gas como recurso estratégico para el logro de una salida útil y soherana al Océano Pacifico?". 
petróleo a favor do país; destine os recursos da exportação e industrialização do gás, principalmente para educação, saúde, caminhos e empregos?."

Vamos a seguir analisar o alcance de cada pergunta.

"l. Você está de acordo com a ab-rogação da Lei de Hidrocarbonetos n. 1.689 promulgada por Gonzalo Sánchez de Lozada? Sim ou-não"

Uma das exigências, dos protestos de outubro de 2003, foi a ab-rogação da Lei de Hidrocarbonetos n. 1.689, de 30 de abril de 1996. Pretendia-se que sua abrogação provocasse a anulação dos contratos celebrados sob sua égide. $\mathrm{O}$ ex-presidente Carlos Mesa declarara que a ab-rogação da Lei de Hidrocarbonetos n. 1.689/96 não implicaria a anulação dos contratos de risco compartilhado ${ }^{55}$ com as empresas petroliferas, celebrados ao amparo desta lei. A lei seria ab-rogada, mas os contratos continuariam vigentes até terminar seu prazo de validade.

A pergunta tem um conteúdo eminentemente generalista. Transmitiria a impressão de que a ab-rogação da Lei de Hidrocarbonetos n. 1.689, de 30 de abril de 1996, permitiria a "recuperação completa" dos hidrocarbonetos, com a anulação dos contratos. O "sim" à ab-rogação da Lei de Hidrocarbonetos n. 1.689/96 daria uma carta branca ao Governo Carlos Mesa para aprovar uma nova lei de hidrocarbonetos sem necessidade de aprovação pública. A nova Lei de Hidrocarbonetos n. 3.058, de 17 de maio de 2005, não foi efetivamente submetida à aprovação popular. Com o resultado favorável ao referendo de 18 de julho de 2004, o ex-presidente Carlos Mesa obteve uma aprovação tácita ao seu próprio projeto de lei. A nova Lei de Hidrocarbonetos foi considerada como sendo muito moderada por segmentos da população boliviana. Voltaram as mobilizações populares, e o Governo Carlos Mesa terminou sendo deposto de maneira semelhante ao de Gonzalo Sánchez de Lozada.

"2. Você está de acordo com a recuperação da propriedade de todos os hidrocarbonetos em boca de poço para o Estado boliviano?"

Havia três artigos na Lei de Hidrocarbonetos n. 1.689, de 30 de abril de 1996, que transfeririam a propriedade dos hidrocarbonetos que já haviam sido extraídos às empresas estrangeiras. Para o art. $1^{\circ}, \S 1^{\circ}$ a exploração dos hidrocarbonetos fazia-se mediante contratos de risco compartilhado celebrados entre o Estado e empresas

s4 Referendo de $18 \mathrm{de}$ julho de 2004, pergunta n. 5: "¿Está usted de acuerdo con que Bolivia exporte gas en el marco de una politica nacional que cubra el consumo de gas de las bolivianas y los bolivianos, fomente la industrialización del gas en territorio nacional, cobre impuestos y/o regalias a las empresas petroleras llegando al 50 por ciento del valor de la producción del gas y el petroleo en favor del pais; destine los recursos de la exporlación e industrialización del gas. principalmente para educación, salud, caminos y empleos?"

ss A expressāo original em castelhano utilizada no direito boliviano é "contratos de riesgo compartido" 
privadas. ${ }^{\text {so }} \mathrm{O}$ art. $5^{\circ}$ previa que "a importação, a exportação e a comercialização" destes hidrocarbonetos era livre. ${ }^{57}$ Para o art. 24, a produção obtida pelas empresas podia ser disposta livremente. ${ }^{58}$ Segundo o ex-presidente Carlos Mesa, os contratos celebrados à luz da Lei de Hidrocarbonetos n. $1.689 / 96$ continuariam vigentes apesar de sua abrogação.

A pergunta n. 2 não explicava que os contratos celebrados não seriam anulados. A nova Lei de Hidrocarbonetos n. 3.058, de 17 de maio de 2005, manteria o mesmo regime de contratos. Esta pergunta foi interpretada por setores da população buliviana como tendo a intenção de dar segurança jurídica às empresas estrangeiras. Não tocaria em absoluto em seus interesses e excluiria definitivamente a sombra de sua expropriação. A Constituição boliviana, art. 139, determina, conforme já tivemos a oportunidade de salientar, que o Estado é o proprietário de suas jazidas de gás e petróleo de maneira direta, inalienável e imprescritível. Mas sem capitais de risco para trazer o gás natural à superficie e comercializá-lo, estar-se-ia nacionalizando gás sem valor algum.

“3. Você estả de acordo com a refundação da Yacimientos Petroliferos Fiscales Bolivianos, recuperando a propriedade estatal das ações das bolivianas e dos bolivianos nas empresas petrolíferas capitalizadas, de maneira que possa participar em toda a cadeia produtiva dos hidrocarbonetos?"

Esta pergunta foi considerada fundamental pelas organizações camponesas e operárias, já que o Estado poderia exercer propriedade plena sobre os hidrocarbonetos apenas através de uma empresa estatal como a YPFB. Para o Governo Carlos Mesa, não se trataria de refundar a YPFB com as características que ela teve antes de sua capitalização, quer dizer como uma empresa estatal que controlasse os hidrocarbonetos em toda a cadeia produtiva. O governo pretenderia refundar a YPFB para que ela pudesse operar somente através de empresas estrangeiras. exercendo a propriedade dos hidrocarbonetos mediante contratos de risco compartilhado. Nem sequer se incluiria a YPFB no processo de transporte ou refino. Não se trataria de refundar uma YPFB que

56 Lei de Hidrocarbonetos n. 1.689, de 30 de abril de 1996, art, $1^{\circ}$, $\$ 1^{\circ}$ : "El derecho de explorar y de explotar los campos de hidrocarburos y comercializar sus productos se ejerce por el Estado mediante Yacimientos Petroliferos Fiscales Bolivianos (YPFB). Esta empresa pública, para la exploración. explotación y comercializacion de hidrocarburos. celebrará necesariamente contratos de riesgo compartido por tiempo lmitado, con personas individnales o colectivas, nacionale's o extranjeras, segin las disposiciones de la presente ley"

57 Lei de Hidrocarbonetos n. 1.689, de 30 de abril de 1996, art. 5": "Es lihre la importación. la exportacion y la comercialización interna de los hidrocarburos y sus productos derivados sujetus a las disposiciones de la presente ley"

58 Lei de Hidrocarbonctos n. 1.689, de 30 de abril de 1996, art. 24: "Quien's celibren contratos de riesgo compartido cun YPFB para la exploración, explotación y comercialización de hidrocarburos adquieren el derecho de prospectar: explotar, extraer: transportar y comercializar la producción obtenida". 
controlasse os hidrocarbonetos e interviesse em sua produção e comercialização, mas de uma YPFB que se encarregasse de celebrar contratos para a prospecção, exploração e comercialização de hidrocarbonetos com empresas estrangeiras. A meta seria criar uma YPFB SAM (Sociedade Anônima de Economia Mista) como uma empresa detentora de ações com capacidade de fiscalização, mas que não interviesse no processo de produção.

“4. Você está de acordo com a política do presidente Carlos Mesa de utilizar o gás como recurso estratégico para conseguir uma saída útil e soberana ao Oceano Pacifico?"

Esta pergunta teria um duplo sentido. Haveria a necessidade vital de a Bolívia ter "uma saída útil e soberana ao Oceano Pacífico", mas de que maneira isto seria conseguido? A política do Governo Carlos Mesa denominada "gás por mar" estaria definida claramente. O objetivo seria obter uma faixa ao Norte do Chile, junto à fronteira do Peru, na qual seria construído um porto boliviano. Em troca, as empresas estrangeiras teriam o direito de exportar gás boliviano ao mercado chileno em condiçõus desfavoráveis para a Bolívia.

A perda do acesso ao mar ć um trauma nacional, mas a questão do acesso ao Oceano Pacífico também seria utilizada para assegurar a exportação de gás ao Chile. Para o ex-presidente Carlos Mesa, o Chile não poderia ter acesso ao gás natural boliviano antes de resolver o problema do acesso ao Oceano Pacífico. A exportação de gás, enquanto isto não fosse resolvido, ocorreria para outros paises. O gás natural seria, então, utilizado como um recurso estratégico pela política exterior boliviana. Essta pergunta evocou no povo boliviano o acesso útil e soberano ao Oceano Pacífico, influenciando seu sentimento patriótico..$^{59}$

"5. Você está de acordo com que a Bolívia exporte gás no marco de uma política nacional que cubra o consumo de gás das bolivianas e dos bolivianos, fomente a industrialização do gás no território nacional, cobre impostos e/ou royalties às empresas petrolíferas chegando a $50 \%$ do valor da produção do gás e do petróleo a favor do país; destine os recursos da exportação e industrialização do gás, principalmente para educação, saúde, caminhos e empregos?"

A questão de fundo desta pergunta seria: "Quem são realmente os agentes que exportam gás"? Se não se anulassem os contratos com as empresas istrangeiras, só elas exportariam e industrializariam o gás boliviano. Para as empresas estrangeiras, seria mais conveniente exportar do que industrializar o gás natural. Mas mesmo que algumas empresas industrializem o gás, sua comercialização seria livre e sua produção se dirigiria

59 O tcma do enclausuramento, da mediterraneidade boliviana. é um tema constante nas relações bolivianuchilenas, sendo tratado em foros intemacionais como a Organização dos Estados Americanos (OEA) e a Organização das Nações Unidas (Onu). 
mais provavelmente ao mercado externo. O processo só beneficiaria as empresas estrangeiras. A primeira parte da pergunta seria uma confirmação da pergunta anterior. Ou seja, se se concorda com a exportação de gás como matéria-prima.

Seria ainda impossível, para as organizações camponesas e operárias, chegar à tributação de " $50 \%$ do valor da produção do gás e do petróleo". A estratégia do Governo Carlos Mesa para atingir tal meta seria simples. Os royalties de $18 \%$ não deveriam aumentar, enquanto que o imposto direto sobre hidrocarbonetos (IDH) ${ }^{60}$ subiria lentamente com o passar dos anos até atingir $32 \%$. Este aumento seria simples especulação. Já fora prometido antes, mas não cumprido. A segunda parte da pergunta, depois de assegurar que o gás atenderia as necessidades nacionais, buscaria o voto favorável de quem estaria de acordo com sua industrialização na Bolívia.

Passamos agora a analisar os resultados do referendo.

O resultado do referendo foi claro. Em 18 de julho de 2004, 60,06\% dos eleitores bolivianos participaram do referendo. Apesar de ter-se imposto a obrigatoriedade do voto. esta consulta popular obteve a mais baixa participação popular desde a transição à democracia. Se o resultado do referendo fosse "não" o ex-presidente Carlos Mesa seria obrigado a mudar completamente a orientação de sua política ou seria obrigado a convocar eleições antecipadas. As cinco perguntas obtiveram os votos necessários para serem consideradas aprovadas. As perguntas n. 1, n. 2 e n. 3 obtiveram mais de $85 \%$ de votos favoráveis. A pergunta n. 2 obteve a mais alta porcentagem de apoio, seguida da pergunta n. 3. A pergunta n. 1, que se havia elaborado para controlar os resultados do referendo e para assegurar seu respaldo, obteve o terceiro lugar na preferência popular. As perguntas n. 4 e n. 5 obtiveram os mais baixos níveis de apoio, mas não foram recusadas. A "recuperação completa" dos hidrocarbonetos daria recursos à Bolívia para a "educação, saúde, caminhos e empregos"; conferiria meios para modernizar o Estado boliviano, em todos os setores. O nível de vida subiria, os impostos baixariam, a Bolívia teria como dar melhores condições de vida a seus habitantes. Havia uma visão redentora e messiânica do resultado do referendo.

O ex-presidente Carlos Mesa sentiu-se então legitimado para aprovar uma nova lei de hidrocarbonetos, a Lei de Hidrocarbonetos n. 3.058, de 17 de maio de 2005. O resultado foi interpretado por ele como uma demonstração de apoio ao seu mandato e a suas politicas. Seu objetivo era iniciar a exportação de gás para o México e Estados Unidos através do Peru e com a colaboração deste país. Mas o que Carlos Mesa não pôde conter foi a resistência do Congresso Nacional, que bloqueava as iniciativas presidenciais. Cada partido tinha sua própria interpretação a respeito do que

the "Impuesto directo a los hidrocarburos (IDH)" 
"recuperação completa" dos hidrocarbonetos significava. O ex-presidente Carlos Mesa e o Congresso Nacional enfrentaram-se pela aprovação do Projeto de Lei de Hidrocarbonetos do Poder Executivo. O conflito circunscrevia-se sobretudo às modificações sobre os impostos e/ou os tipos de impostos que deveriam ser adotados para aumentar o governmet take. Após vários meses de análise e debate, o Congresso Nacional boliviano aprovou a Lei de Hidrocarbonetos n. 3.058/05. Fixou-se um royalty de $18 \%$ e um imposto ${ }^{\circ 1}$ de $32 \%$ a ser cobrado das empresas estrangeiras. ${ }^{62}$

O ex-presidente Carlos Mesa, a despeito da aprovação da Lei de Hidrocarbonetos n. 3.058, de 17 de maio de 2005, não conseguiu criar um consenso sobre a política do Estado boliviano para o gás e petróleo em torno da expropriação das empresas estrangeiras. Segmentos da sociedade boliviana continuavam a exigir um royalty petrolífero de $50 \%$. A interpretação dos resultados das cinco perguntas do referendo foi o fator mais significativo para que se acentuasse a deterioração das relações entre o ex-presidente Carlos Mesa e o Congresso Nacional. Como ponto culminante neste processo de deterioração, Carlos Mesa. acossado por um levante semelhante àquele enfrentado anteriormente pelo ex-presidente Gonzalo Sánchez de Lozada, renunciou em 7 de junho de 2005 à Presidência da República.

\section{Lei de Hidrocarbonetos}

A Bolívia já teve várias leis de hidrocarbonetos no decorrer de sua história. Seu conteúdo variou, dependendo das contingências políticas. Umas reforçaram o papel da YPFB, a estatal boliviana do gás e petróleo, outras restringiram sua missão, prevendo que, por exemplo, não the caberia industrializar o gás natural. A função básica da YPFB tem sido o manejo de reservas. ${ }^{63}$ Às empresas estrangeiras tem cabido tradicionalmente a prospecção, exploração e comercialização do gás e petróleo. Os levantes populares que levaram os ex-presidentes Gonzalo Sánchez de Lozada e Carlos Mesa à renúncia tiveram como objetivo primordial modificar esta situação. Pleiteava-se a anulação dos contratos celebrados com empresas estrangeiras, a reversão das jazidas de hidrocarbonetos e o

"A Lei de Hidrocarbonetos n. 3.058. de 17 de maiu de 2005, art. 53, deu origem ao "impuesto directo a los hidrocarburos" (IDH): "Créase el Impuesto Directo a los Hidrocarburos (IDH). que se aplicará, en lodo el territorio nacional, a la producción de hidrocarburos en Boca de Pozo, que se medirá y pagará como las regalias, de acuerdo a lo establecido en la presente Ley y su reglamentación".

62 Lei de Hidrocarbonetos n. 3.058, de 17 de maio de 2005. art. 55, $\$ 3^{\circ}$ : "La sumaloria de los ingresos establecidos del $18 \%$ por Regalias y del $32 \%$ del Impuesto Directo a los Hidrocarburos (IDH). no seri en ninguin caso menor al cincuenta por ciento $(50 \%)$ del valor de la producción de los hidrocarburos en favor del Eslado Boliviano, en concordancia con el Arliculo $8^{\circ}$ de la presente ley"

63 O Governo do gencral Hugo Banzer Suárez, no inicio da década de setenta do século passado. reduziu consideravelmente o campo de atuação da YPFB, também sendo acusado à época de tê-la "privatizado" 
fortalecimento da YPFB para que ela passasse a ter competência justamente para a prospecção, exploração e comercialização do gás e petróleo.

A Lei de Hidrocarbonetos n. 1.689, de 30 de abril de 1996, previa, no entanto, art. $1^{\circ}$ caput, em conformidade com o previsto na Constituição boliviana, art. 139, que o Estado era proprietário das jazidas de gás e petróleo: "Por norma constitucional, as jazidas de hidrocarbonetos, qualquer que seja o estado em que se encontrem ou a forma em que se apresentem, são do domínio direto, inalienável e imprescritivel do Estado. Nenhuma concessão ou contrato poderá conferir a propriedade das jazidas de hidrocarbonetos" "A YPFB celebrava contratos de concessão com empresas estrangeiras para a prospeç̧ão, exploração e comercialização de hidrocarbonetos: "O direito de prospectar e de explorar os campos de hidrocarbonetos e de comercializar seus produtos exerce-se pelo Estado mediante Yacimientos Petrolíferos Fiscales Bolivianos (YPFB). Esta empresa pública, para a prospeç̧ão, exploração e comercialização de hidrocarbonctos, celebrará necessariamente contratos de risco compartilhado, por tempo limitado, com pessoas físicas ou juridicas, nacionais ou estrangeiras, segundo as disposições da presente lei" (Lei de Hidrocarbonetos n. $1.689 / 96$, art. $\left.1^{\circ} \S 1^{\circ}\right)^{65}$

A meta primordial da Lei de Hidrocarbonetos n. 3.058/05. art. $2^{\circ}$, foi "a exccução e cumprimento dos resultados do Referendo de 18 de julho de 2004, que expressam a decisão do povo da Bolivia" ${ }^{66} \mathrm{O}$ cumprimento desta mela implicou a abrogação da Lei de Hidrocarbonetos n. 1.689/96. ${ }^{67} \mathrm{O}$ caráter estratégico do gás natural para a política exterior boliviana foi estabelecido de imediato: "Reconhece-se o valor do gás natural e demais hidrocarbonetos como recursos estratégicos, que colaborem com os objetivos de desenvolvimento econômico e social do país e com a política exterior do

at Lei de Hidrocarbonetos n. 1.689, de 30 de abril de 1996, art. $1^{\circ}$, caput: "Por norma constitucional, los yacimientos de hidrocarburos. cualquiera sea el estado en que se encuentren o la forma en que se presenten. son del dominio directo. inalienable e imprescriptible del Estado. Ninguna concesión o contrato podrá conferir la propiedad de los yacimientos de hidrocarburos"

65 Lei de Hidrocarbonctos n. 1.689, de 30 de abril de 1996, an. 1", § 1": "El derecho de explorar y de explotar los campos de hidrocarburos y comercializar sus productos se ejerce por el Estado mediante Yacimientos Petroliferus Fiscales Bolivianos (YPFB). Esta empresa puiblica, para la exploración. explotacion y comercializacion de hidrocarburos, celebrará necesariamente contratos de riesgo compartido por tiempo limitado. con personas individuales o colectivas, nacionales o extranjeras, segün las disposiciones de la presente ley"

6. Lei de Hidrocarbonetos n. 3.058, de 17 de maio de 2005, art. $2^{\circ}$ : "Este capitulo tiene por objero la ejecución y cumplimiento de los resultudos del Referéndum del 18 de julio de 2004. que expresan la decisión del puehlo de Bolivia"

67 Lei de Hidrocarbonetos n. 3.058, de 17 de maio de 2005, art. 30: "Se abroga la Lev de Hidrocarburos $N^{\circ}$ 1689. de 30 de abril de 1996". 
Estado boliviano, incluindo a conquista de uma saída útil e soberana ao Oceano Pacífico" (Lei de Hidrocarbonetos n. 3.058/05, art. $\left.4^{\circ}\right)^{6.8}$

A "recuperação completa" dos hidrocarbonetos foi prevista pela Lei de Hidrocarbonetos n. 3.058/05, art. $5^{\circ}$, caput: "Por mandato soberano do povo boliviano, expressado na resposta à pergunta número 2 do Referendo Vinculante de 18 de julho de 2004, e cm aplicação ao art. 139 da Constituição Política do Estado, recupera-se a propriedade de todos os hidrocarbonetos em boca de poço para o Estado boliviano. O Estado exercerá, através de Yacimientos Petrolíferos Fiscales Bolivianos (YPFB), seu direito proprietário sobre a totalidade dos hidrocarbonetos" ${ }^{69}$ Previu-se a renegociação dos contratos celebrados com empresas estrangeiras: "Os titulares que tiverem subscrito contratos de risco compartilhado para executar as atividades de prospecção, exploração e comercialização, e tiverem obtido licenças e concessões ao amparo da Lei de Hidrocarbonetos n. 1.689, de 30 de abril de 1996, deverão converter-se obrigatoriamente às modalidades de contratos estabelecidas na presente Lci e adequar-se a suas disposições no prazo de cento e oitenta (180) dias-calendário computáveis a partir de sua vigência" (Lei de Hidrocarbonetos n. 3.058/05, art. $5^{\circ} \S 1^{\circ}$ )..$^{\text {n }}$

O Poder Executivo consagrou-se como responsável pela política de exportação e industrialização do gás natural: "O Poder Fxecutivo, dentro do regime econômico estabelecido na Constituição Política do Estado, será responsável por: a) Estabelecer a política para o desenvolvimento e abertura de mercados para a exportação de gás. b) Promover o consumo maciço do gás em todo o território nacional para melhorar a qualidade de vida dos bolivianos, dinamizar a base produtiva e elevar a competitividade da economia nacional. c) Desenvolver a política e os incentivos para a industrialização do gás no território nacional. d) Fomentar a participação do setor privado na exportação do gás e sua industrialização" (Lei de Hidrocarbonetos n.

68 Lei de Hidrocarbonetos n. 3.058, de 17 de maio de 2005, art. 4०: "Se reconoce el valor del Gas Natural y demás hidrocarburos como recursos estratégicos, que coadyuven a los objetivos de desarrollo económico y social del pais y a la politica exterior del Estado Boliviano, incluyendo el logro de una salida uitil v soberana al Océano Pacifico"

6 Lei de Hidrocarbonetos n. 3.058, de 17 de maio de 2005. ant. 5०, caput: "Por mandaro soberano del pueblo boliviano, expresado en la respuesta a la pregunta múmero 2 del Referéndum Vinculante de 18 de julio de 2004. y en aplicación del Articulo $139^{\circ}$ de la Constitución Politica del Estado, se recupera la propiedad de todos los hidrocarburos en Boca de Pozo para el Estado Boliviano. El Estado ejercerá, a través de Yacimientos Petroliferos Fiscales Bolivianos (YPFB). su derecho propietario sobre la toralidad de los hidrocarburos"

70 Lei de Hidrocarbonetos n. 3.058, de 17 de maio de 2005, art. 5०, § $1^{\circ}$ : "Los Titulares que hubieran suscrito Contratos de Riesgo Compartido para ejecutar las actividades de Exploración, Explotación y Comercializacion, y hubieran obtenido licencias y concesiones al amparo de la Ley de Hidrocarburos $N^{o}$ 1689. de 30 de abril de 1996, deberán convertirse obligatoriamente a las modalidades de contratos estahlecidas en la presente Ley, y adecuarse a sus disposiciones en el plazo de ciento ochenta (180) dias calendario computables a partir de su vigencia" 
$3.058 / 05$, art. $7^{\circ}$, caput $) .^{71}$ Indo ao encontro do que fora pleiteado no levante popular que levara Gonzalo Sánchez de Lozada à renúncia, reconheceu-se que as rendas auferidas com a exportação e industrialização do gás deveriam ser utilizadas para combater a pobreza: "O Poder Executivo destinará as rendas nacionais provenientes da exportação e industrialização do gás, principalmente, em atenção à educação, saúde, caminhos e empregos" (Lei de Hidrocarbonetos n. 3.058/05, art. $7^{\circ}$ parágrafo único). ${ }^{72}$ Para que esse objetivo fosse alcançado, o nível de apropriação da renda das empresas estrangeiras pelo Estado boliviano precisou realmente aumentar: "Dispõe-se que o Estado reterá cinqüenta por cento $(50 \%)$ do valor da produção de gás e do petróleo, conforme o mandato contido na resposta da pergunta número 5 da Lei do Referendo Nacional de 18 de julho de 2004" (Lei de Hidrocarbonetos n. 3.058/05, art. $8^{\circ}$ ). ${ }^{73}$ "A soma das rendas estabelecidas de $18 \%$ por royalties e de $32 \%$ do imposto direto sobre hidrocarbonetos (IDH) não será em nenhum caso menor do que cinqüenta por cento $(50 \%)$ do valor da produção dos hidrocarbonetos em favor do Estado boliviano, em concordância com o art. $8^{\circ}$ da presente lei" (Lei de Hidrocarbonetos n. 3.058/05, art. 55, § $\left.3^{\circ}\right)^{74}$

Os objetivos da política nacional de hidrocarbonetos foram orientados por uma lógica eminentemente soberanista e estatal: "Constituem objetivos gerais da política nacional de Hidrocarbonetos: (...) b) Exercer o controle e a direção efetiva, por parte do Estado, da atividade hidrocarburífera em resguardo à sua soberania política e econômica (...) e) Fortalecer, técnica e economicamente, a Yacimientos Petrolíferos Fiscales Bolivianos (YPFB) como a empresa estatal encarregada de executar a Política Nacional de Hidrocarbonetos para garantir o aproveitamento soberano da indústria hidrocarburífera" (Lei de Hidrocarbonetos n. 3.058/05, art. 11). ${ }^{75}$

7 Lei de Hidrocarbonetos n. 3.058, de 17 de maio de 2005, art. $7^{\circ}$, caput: "El Poder Ejecurivo, dentro del Régimen Económico estublecido en la Constitnción Politica del Estado. será responsuble de: a) Establecer la politica para el desarrollo y apertura de mercados para la Exportación del gas. b) Promover el consumo masivo del gas en todo el territorio nacional para mejorar la calidad de vida de los bolivianos, dinamizar la base productiva y elevar la competitividad de la economia nacional. c) Desarrollar la politica y los incentivos para la Industrialización del Gas en el territorio nacional. d) Fomentar la participación del sector privado en la Exportación del Gas y su Industrialización"

72 Lei de Hidrocarbonetos n. 3.058, de 17 de maio de 2005. art. $7^{\circ}$. parágrafo único: "El Poder Ejecurivo destinara los ingresos nacionales provenientes de la cxportación e industrialización del gas, principalmente, a la atención de la educación, salud, caminos y empleos"

73 Lei dc Hidrocarbonetos n. 3.058, de 17 de maio de 2005, art. $8^{\circ}$ : "Se dispone que el Estado retendrá el cincuenta por ciento (50\%) del valor do la producción de gas y del petróleo. conforme al mandato contenido en la respuesta de la pregunta mimero 5 de la Ley del Referéndum Nacional de 18 de julio de $2004 "$

74 Lei de Hidrocarbonetos n. 3.058, de 17 de maio de 2005, art. 55, \$ 3: "La sumatoria de los ingresos establecidos del 18\% por Regalias y del 32\% del Impuesto Directo a los Hidrocarburos (IDH), no será en ningion caso menor al cincuenta por ciento (50\%) del valor de la producción de los hidrocarburos en favor del Estado Boliviano. en concordancia con el Articulo $8^{\circ}$ de la presemte ley" 
À maneira da Lei de Hidrocarbonetos n. 1.689, de 30 de abril de 1996, a Lei de Hidrocarbonetos n. 3.058, de 17 de maio de 2005, em consonância novamente com o previsto na Constituição boliviana, reconheceu que as jazidas de gás e petróleo pertencem ao Estado: "As jazidas de hidrocarbonetos, qualquer que seja o estado em que se encontrem ou a forma em que se apresentem, são de domínio direto, inalienável e imprescritível do Estado. $\S 1^{\circ}$ Nenhum contrato pode conferir a propriedade das jazidas de hidrocarbonetos nem dos hidrocarbonetos em boca de poço nem até o ponto de fiscalização. $\S 2^{\circ} \mathrm{O}$ titular de um contrato de produção compartilhada, operação ou associação está obrigado a entregar ao Estado a totalidade dos hidrocarbonetos produzidos nos termos contratuais que sejam estabelecidos por este" (Lei de Hidrocarbonetos n. 3.058/05, art. 16) ${ }^{76}$ Contratos de concessão foram previstos como o instrumento jurídico permitindo às empresas estrangeiras assumir a prospecção, exploração e comercialização de hidrocarbonetos: "A prospeç̧ão, exploração, comercialização, transporte, armazenagem, refino e industrialização dos hidrocarbonetos e seus derivados correspondem ao Estado, direito que será exercido por si mediante entidades autárquicas ou através de concessões e contratos por tempo limitado, a sociedades mistas ou a pessoas privadas, conforme a lei" (Lei de Hidrocarbonetos $n$. 3.058/05, art. 17, inciso I).$^{77} \mathrm{O}$ Ministério dos Hidrocarbonetos ficou encarregado de definir a política de preços: "O Ministério dos Hidrocarbonetos, em matéria de hidrocarbonetos, tem como atribuições as seguintes: (...) d) Determinar os preços dos hidrocarbonetos no ponto de fiscalização para o pagamento dos royalties, retribuições e participações, de acordo com as normas estabelecidas na presente lei" (Lei de Hidrocarbonetos n. 3.058/05, art. 21). ${ }^{78}$

? Lei de Hidrocarbonetos n. 3.058, de 17 de maio de 2005, art. 11: "Constituyen objetivos generales de la Politica Nacional de Hidrocarburns: (...) b) Fjercer el control y la dirección efectiva, por parte del Estado, de la actividad hidrocarburifera en resguardo de su soberania política y económica. (...) e) Fortalecer, técnica y económicamente, a Yacimientos Petroliferos Fiscales Bolivianos (YPFB) como la empresa estatal encargada de ejecular la Politica Nacional de Hidrocarburos para garantizar el aprovechamiento soberano de la industria hidrocarburifera"

${ }^{26}$ Lei de Hidrocarbonetos n. 3.058, de 17 de maio de 2005, ant. 16: "Los yacimientos de hidrocarburos, cualquiera que sea el estado en que se encuentren o la forma en que se presenten, son de dominio directo. inalienable e imprescriptible del Estado. $\$ 1^{\circ}$ Ningin contrato puede conferir la propiedad de los yacimientos de hidrocarburos ni de los hidrocarburos en Boca de Pozo ni hasta el pumto de fiscalizacion. $\S 2^{\circ}$ El Titular de un Contrato de Producción Compartida. Operación o Asociación está obligado a entregar al Estado, la totalidad de los Hidrocarburos producidos en los terminos contractuales que sean establecidos por éste"

7 Lei de Hidrocarbonetos n. 3.058, de 17 de maio de 2005, art. 17, inciso I: "La exploración, explotación, comercializacion. Iransporte, almacenaje, refinación $e$ industrialización de los hidrocarburos y sus derivados corresponden al Estado. derecho que será ejercido por si, mediante entidades autárquicas o a través de concesiones y contralos por tiempo limilado. a sociedades mixias o a personas privadas. cunforme a ley" 
A Lei de Hidrocarbonetos n. 3.058/05, art. 65, estabeleceu que o prazo máximo de vigência dos contratos celebrados com empresas estrangeiras é de "quarenta (40) anos" 79 A produção, novamente de acordo com a Lei de Hidrocarbonetos n. 3.058/05, art. 66, tem de ser entregue à Yacimientos Petroliferos Fiscales Bolivianos (YPFB), em troca da retribuição prevista em contrato. ${ }^{\circ 0}$ Os contratos, sempre à luz da Lei de Hidrocarbonetos n. 3.058/05, art. 68, devem ser "autorizados e aprovados, em conformidade com o disposto no art. 59, inciso V, da Constituição Política do Estado" 81

\section{Contrato entre a Petrobras e a Yacimientos Petrolíferos Fiscales Bolivianos (YPFB)}

O contrato de compra e venda de gás natural entre a Petrobras e a YPFB foi celebrado em 16 de agosto de 1996. Contém uma cláusula take or pay. ${ }^{k 2}$ determinando que a Petrobras precisará pagar pelo gás natural negociado mesmo que não o consuma. ${ }^{83} \mathrm{O}$ contrato estabelece o volume de venda, a forma de medição do volume, como os preços serão ajustados e a quem o gás será entregue. Seu prazo de vigência é de 20 (vinte) anos, contados "a partir do início do abastecimento, podendo ser prorrogado por acordo das Partes" ${ }^{\$ 4}$

Nos consideranda, alude-se ao instrumento assinado pelo Brasil e Bolívia que deu ensejo à celebração do contrato: "Que na data de 26 de novembro de 1991, na

78 Lei de Hidrocarbonctos n. 3.058, de 17 de maio de 2005, ant. 21: "El Ministerio de Hidrocarburos, en materia di hidrocarburos, tiene como atribuciones las signientes: (...) d) Determinar los precios de los hidrocarburos en el Punto de Fiscalización para el pago de las regalias, retribuciones y participaciones. de acuerdo a las normas establecidas en la presente Ley."

79 Lei de Hidrocarbonetos n. 3.058, de 17 de maio de 2005, art. 65: "Cualquier persona individual o colectiva, nacional o extranjera, puiblica o privada podrá celehrar con Yacimientos Petroliferos Fiscales Bolivianos (YPFB) uno o más ('ontratos de Producción Compartida. Operación o Asociación para ejecular actividades deExploración y Explotación, por un plazo que no excederá los cuarenta (40) años".

so Lei de Hidrocarbonetos n. 3.058, de 17 de maio de 2005, art. 66: "Una vez iniciada la producción, el Titular está obligado a entregar a Yacimientos Petroliferos Fiscales Bolivianos (YPFB). la totalidad de los hidrocarburos producidos"

si Lei de Hidrocarbonetos n. 3.058. de 17 de maio de 2005, ant. 68: "Los Contratos di' Producción Compurtida. Operacion. Asociación y sus modificaciones, deberán ser autorizados y aprobados. de

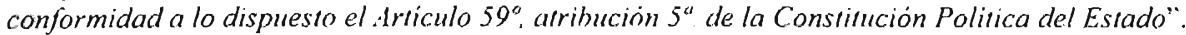

82 A cláusula take or pay é resumidamente uma cláusula de consumo e transporte minimos.

83 Contrato de Compra e Venda de (jás Natural entre Petrobras S.A. e YPFB, subcláusula 4.1.: "El Suministro por YPFB y la recepción por PETROBRAS del Gas en el Punto de Entrega, será de ocho millones de Metros Cúbicos de Gas por Dia (8.000.000 $\mathrm{m}^{3} / \mathrm{Dia}$ ) en el primer Año. a partir del Inicio del Suministro. incrementandose Año por Año. de acuerdo con los volumenes establecidos en el Anexo $I$. hasta alcanzar dieciséis millones de Metros Cubicos de Gas por Dia (16.000.000 $\mathrm{m}^{3} /$ Dia) durante el primer Mes del octavo Año. manteniendo este nivel hasta la finalización del (ontrato (negrito nosso)"

84 Contrato de Compra e Venda de Gás Natural entre Petrobras S.A. e YPFB, subcláusula 20.1.: "El Contrato entrará en vigencia y' será obligatorio para las Partes, a partir de la fécha de su suscripción y tendrá (...) un plazo de duración de veinte (20) Años computahle a partir del Inicio del Suministro, pudiendo ser prorrogado por acuerdo de Partes (...)" 
cidade de La Paz, foi assinada uma Carta de Intenções sobre o Processo de Integração Energética entre Bolívia e Brasil, por Petrobras, YPFB e o Ministério da Energia e Hidrocarbonetos da República da Bolívia" 85 “(...) YPFB por sua vez decidiu chegar a um acordo com Petrobras para abastecer com gás natural o mercado brasileiro e adotar as medidas necessárias para assegurar a disponibilidade dos volumes anteriormente citados" ${ }^{86}$ A compra e venda de gás foi considerada um fator fundamental na integração da Bolívia com o Brasil: "Que o ministro das Minas e Energia da República Federativa do Brasil e o ministro da Energia e Hidrocarbonetos da República da Bolívia, reunidos nos dias 25 e 26 de maio de 1992, na cidade de Brasilia, declararam que a compra-venda de Gás Natural é uma decisão política prioritária para o processo de integração do Brasil e da Bolívia e para o crescimento econômico de ambos os países" ${ }^{87}$

O objeto do contrato é a compra pela Petrobras e a venda pela YPFB de gás natural por “(...) um prazo de vinte (20) anos computados a partir do Início do Abastecimento, podendo ser prorrogado por acordo das partes" (Contrato, subcláusula 2.1.) ${ }^{88}$ A construção do gasoduto teve como meta abastecer as regiões Sul e Sudeste do Brasil, sobretudo o Fstado de São Paulo ${ }^{89} \mathrm{O}$ contrato prevê um sistema minucioso de ajuste de preços: "O preço do Gás, em US\$/MMBtu, em Rio Grande, Bolívia, para cada Ano, na entrada do Gasoduto, é o que consta no seguinte quadro, preço que será denominado daqui em diante o P(i), sendo (i) o ano contratual de referência" (Contrato, subcláusula 11.1.). ${ }^{90}$ As cláusulas contratuais podem ser revistas por solicitação das partes: "Sem interromper nem suspender os prazos fixados para o cumprimento das

85 Contrato de Compra e Venda de Gás Natural entre Petrobras S.A. e YPFB, consideranda: "Que en fecha 26 de noviembre de 1991, en la ciudad de La Paz. fue firmada una Carta de Intenciones sobre el Proceso de Integración Energética entre Bolivia y Brasil, por PETROBRAS, YPFB y el Ministerio de Energia e Hidrocarburos de la República de Bolivia"

86 Contrato de Compra e Venda de Gás Natural entre Petrobras S.A. e YPFB, consideranda: "(...) YPFB a su vez decidió llegar a un acuerdo con PETROBRAS para abastecer gas natural al mercado brasileño $y$ adoptar las medidas necesarias para asegurar la disponibilidad de los volumenes anteriormente citados"

87 Contrato de Compra e Venda de Gás Natural entre Petrobras S.A. e YPFB, consideranda: "Que el Ministro de Minas y Energia de la República Federativa del Brasil y el Ministro de Energia e Hidrocarburos de la Repuiblica de Bolivia, reunidos los dias 25 y 26 de mayo de 1992, en la ciudad de Brasilia. declararon yue la compra - venta de Gas Natural es una decisión politica prioritaria para el proceso de integracion del Brasil y de Bolivia y para el crecimiento económico de ambos paises"

88 Contrato de Compra e Venda de Gás Natural entre Petrobras S.A. e YPFB, subcláusula 2.1.: “(..) um plazo de veinte (20) Años computados a partir del Inicio del Suministro, pudiendo ser prorrogudo por acuerdo de Parles"

89 Contrato de Compra e Venda de Gás Natural entre Petrobras S.A. e YPFB, subcláusula 3.6.: "El Proyecto del Gasoducto se basa en el abastecimiento de los mercados industriales, de generación termoelectrica, de transporte. comercial y residencial y otros de las regiones Sur y Sudeste (...)"

90 Contrato de Compra e Venda de Gás Natural entrc Petrobras S.A. e YPFB, subcláusula 11.1.: "El precio del Gas, en US\$/MMBiu. en Rio Grande. Bolivia. para cada Año. en la entrada del Gasoduclo. es el que consta en el siguiente cuadro. precio que será denominado de aqui en adelanti el $P(i)$. siendo (i) el año contracual de referincia" 
obrigações das Partes, fica reservado o direito das Partes de solicitarem-se mutuamente reuniões, que não poderão ser negadas para discutir qualquer Cláusula de índole técnica, econômica e comercial, em caso de apresentarem-se alterações supervenientes, incluindo as motivadas pela evolução dos preços do mercado energético internacional, que possam afetar as bases nas quais tais Cláusulas foram acordadas e que prejudiquem quaisquer das Partes" (Contrato, subcláusula 15.1.). ${ }^{91}$

O processo de solução de controvérsias envolve o recurso à arbitragem: "Qualquer disputa, controvérsia ou reclamação que se suscite por ou em relação com o Contrato entre as Partes solucionar-se-á inicialmente por discussão, consulta e negociação entre as Partes" (Contrato, subcláusula 17.1.). "2 "Todas as disputas, controvérsias e reclamações que podiam suscitar-se da interpretação ou cumprimento de qualquer das Cláusulas do Contrato e que não forem solucionadas pelas Partes conforme o estabelecido na Subcláusula 17.1. da presente Cláusula, dentro de um prazo de sessenta (60) dias, submeter-se-ão exclusivamente à American Arbitration Association de Nova York, aplicando-se seu Regulamento sobre Arbitragem Internacional" (Contrato. subcláusula 17.2.). "A decisão majoritária dos árbitros será apresentada por escrito e será obrigatória e inapelável" (Contrato, subcláusula 17.5.). ${ }^{94}$

\section{Decreto Supremo}

Em $1^{\circ}$ de maio de 2006, o presidente Evo Morales, ao completar seus 100 primeiros dias de governo, promulgou o Decreto Supremo n. 28.701, anunciando a

9 Contrato de Compra e Venda de Gảs Natural entre Petrobras S.A. e YPFB, subcláusula 15.1.: "Sin interrumpir ni suspender los plazos fijados para el cumplimiento de las obligaciones de las Partes, queda salvado el derecho de las Partes para solicitarse inutuamente reuniones. qu' no podrán ser negadas, para discutir cualquier Cláusula de indole técnico, económico y comercial, en caso d' presentarse alteraciones sobrevinientes. incluyendu las motivadas por la evolución de los precios del inercado energético intemacional, que puedan afectar las bases en que tales Clausulas fueran acordadas y que perjudiquen a cualquiera de las Partes"

92 Contrato de Compra e Venda de Gás Natural entre Petrobras S.A. e YPFB, subcláusula 17.1.: "( iralquier disputa, controversia o reclamo que sc suscitc por o en relación con el Contrato entre las Partes se soluciunará inicialmente por discusión, consulta y negociación entre las Partes"

93 Contrato de Compra e Venda de Gás Natural entre Petrobras S.A. e YPFB, subcláusula 17.2.: "Todas las disputas, controversias y reclamos que podian suscitarse de la interpretación o cumplimiento de cualquiera de las Cláusulas del Contrato "que no fueran solucionadas por las Parles conforme con lo establecido en la Subcláusula 17. I de la presente Cláusula, dentro de un plazo de sesenta (60) dias, se someterán exclusivamente a la American Arbitration Association de New York aplicándose su Reglamento sobre Arhitraje Internacional'

9. Contrato de Compra e Venda de Gás Natural entre Petrobras S.A. e YPFB, subcláusula 17.5.: "El fallo mayoritario de los árbitros será preséntado por escrito y será obligatorio e inapelable" 
"recuperação completa" do gás e petróleo. ${ }^{95} \mathrm{O}$ decreto contém, logo em seu início, uma evocação aos "heróis do Chaco" 96 Na Guerra do Chaco, ocorrida de 1932 a 1935, a Bolívia, conforme já pudemos ressaltar previamente, perdeu para o Paraguai um vasto território no qual se acreditava ter petróleo.

Os consideranda remetem a "recuperação completa" do gás e petróleo aos levantes populares que levaram os ex-presidentes Gonzalo Sánchez de Lozada e Carlos Mesa à renúncia: "Que em históricas jornadas de luta, o povo conquistou à custa de seu sangue o direito de que nossa riqueza hidrocarburifera volte às mãos da Nação (...)" ${ }^{97} \mathrm{O}$ Decreto Supremo n. 28.701/06 foi adotado como uma resposta ao referendo de 18 de julho de 2004, no qual o eleitorado teria decidido em favor da "recuperação completa" dos hidrocarbonetos. O referendo não contemplou, no entanto, nenhuma pergunta sobre a expropriação das empresas estrangeiras. Houve uma pergunta sobre a propriedade dos hidrocarbonetos em "boca de poço" Tampouco no referendo o eleitorado votou pela propriedade, posse e controle total e absoluto destes recursos. $\dot{A}$ luz da Constituição boliviana, arts. 136, 137 e 139. o gás e petróleo pertencem ao Estado de maneira direta, inalienável e imprescritível. Constituem propriedade pública inviolável. A "recuperação completa" do gás e petróleo precisaria passar, então, pela expropriação das empresas estrangeiras, partindo-se do pressuposto de que os contratos com elas celebrados podiam ser anulados por vício de forma. Eles não teriam sido autorizados e aprovados pelo Poder Legislativo, uma exigência estipulada pela Constituição boliviana, art. $59, \S 5^{\circ} 98$ A linguagem adotada pelo Decreto Supremo n. 28.701/06 é contundente: "Que o chamado processo de capitalização e privatização de Yacimientos Petrolíferos Fiscales Bolivianos YPFB significou não somente um grave dano econômico ao Estado, mas ademais um ato de traição à pátria ao entregar a mãos estrangeiras o controle e a direção de um setor estratégico, vulnerando a soberania e a dignidade nacionais" 99

\footnotetext{
95 No Direito boliviano, o decreto supremo é uma norma aprovada pelo presidente da República com base em sua competência administrativa e regulamentar.

96 "Héroes del ('haco"

97 Decreto Supremo n. 28.701, de $1^{\circ}$ de maio de 2006. consideranda: "Que en históricas jornadas de lucha. el pueblo ha conquistado a costa de su sangre. el derecho de que nuestra riqueza hidrocarburifera vuelva a manos di la Nación (...)"

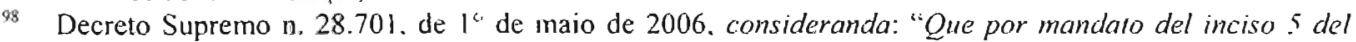
Articulo 59 de la Constitución Politica del Estado. los contratos de explotación de riquezas nacionales deben ser autorizados y aprobados por el Poder Legislativo (...)"

99 Decretu Supremo n. 28.701, de $1^{\circ}$ de maio de 2006. consideranda: "Que el llamado proceso de capitalización y privatización de Yacimientos Petroliferos Fiscales Bolivianos YPFB ha significado no sólo un grave daño económico al Estado, sino ademús un acto de traición a la patria al entregar a manos extranjeras al control y la dirección de un sector estratégico, vulnerando la soberania $v$ la dignidad nacionales"
} 
A "recuperação completa" do gás e petróleo é anunciada como o objetivo primordial a ser alcançado: "O Estado recupera a propriedade, a posse e o controle total e absoluto destes recursos" (Decreto Supremo n. 28.701/06, art. $1^{\circ}, \S 1^{\circ}$ )..$^{100}$ "A partir de $1^{\circ}$ de maio de 2006, as empresas petroliferas que atualmente realizam atividades de produção de gás e petróleo no território nacional estão obrigadas a entregar em propriedade a Yacimientos Petrolíferos Fiscales Bolivianos - YPFB toda a produção de hidrocarbonetos" (Decreto Supremo n. 28.701/06, art. $2^{\circ}$ inciso I) ${ }^{101}$ "YPFB, em nome e em representação do Estado, no exercício pleno da propriedade de todos os hidrocarbonetos produzidos no país, assume sua comercialização, definindo as condições, volumes e preços tanto para o mercado interno, como para a exportação e a industrialização" (Decreto Supremo n. 28.701/06, art. $2^{\circ}$ inciso II). ${ }^{102}$ A Lei de Hidrocarbonetos n. 3.058, de 17 de maio de 2005, atualmente vigente, não permite que o Estado estabeleça unilateralmente preços de exportação do gás natural. Altera-se, assim, uma lei mediante decreto, o que é inconstitucional. "Só poderão continuar operando no país as companhias que acatem imediatamente as disposições do presente Decreto Supremo, até que num prazo não superior a 180 dias desde sua promulgação se regularize sua atividade, mediante contratos que cumpram as condições e requisitos legais e constitucionais. Ao término deste prazo, as companhias que não tenham assinado contratos não poderão continuar operando no país" (Decreto Supremo n. 28.701/06, art. $3^{\circ}$ inciso I). ${ }^{103}$ Serão convidadas a abandonar a Bolívia.

"Durante o periodo de transição, para os campos cuja produção comprovada na média de gás natural do ano de 2005 tenha sido superior a 100 milhões de pés cúbicos diários, o valor da produção distribuir-se-á da seguinte forma: $82 \%$ para o Estado ( $18 \%$ de royalties e participações, $32 \%$ de imposto direto sobre hidrocarbonetos IDH e $32 \%$ através de uma participação adicional para a YPFB), e $18 \%$ para as

100 Decreto Supremo n. 28.701 , de $1^{\circ}$ de maio de 2006, ant. $1^{\circ} . \$ 1^{\circ}$ : "El Estudo recupera la propiedad, la posesión y el control total y absoluto de estos recursos"

101 Decreto Supremo n. 28.701, de $1^{\circ}$ de maio de 2006, ant. $2^{\circ}$, inciso I: "A parir del l de mayo del 2006, las empresus petroleras que achualmente realizan actividades de producción de gas y petróleo en el territorio nacional. están obligadas a entregar en propiedad a Yacimientos Petroliferos Fiscales Bolivianos - YPFB. toda la producción de hidrocarburos"

102 Decreto Supremo n. 28.701. de $1^{\circ}$ de maio de 2006, art. $2^{\circ}$, inciso II: "YPFB, a nombre y en representución del Estado. en ejercicio pleno de la propiedad de todos los hidrocarburos producidos en el pais, asume su comercialización, definiendo las condiciones, volumenes y precios tanto para el mercado interno. como para la exportación y la industrialización"

103 Decreto Supremo n. 28.701, de $1^{\circ}$ de maio de 2006, art. $3^{\circ}$, inciso I: "Sólo podrán seguir operando en el pais las compañias que acaten inmediatamente las disposiciones del presente Decreto Supremo, hasta que en un plazo no mayor a 180 dias desde su promulgacion. se regularice su actividad, mediante contratos, que cumplan las condiciones y requisitos legales y constitucionales. Al termino de este plazo. las compañias que no hayan firmado cuntratos no podrán seguir operando en cl pais" 
companhias (que cobre custos de operação, amortização de investimentos e utilidades)" (Decreto Supremo n. 28.701/06, art. $4^{\circ}$ inciso I). ${ }^{104}$ Nesta faixa de produção diária "superior a 100 milhões de pés cúbicos diários" encaixam-se apenas os campos de San Alberto e San Antonio, operados pela Petrobras e de onde provém cerca de metade do volume de gás importado pelo Brasil. O art. $4^{\circ}$, inciso I, foi redigido tendo em vista a Petrobras. Os $82 \%$ incidiriam apenas durante a fase de transição de 180 dias. Este aumento do government take reduz a rentabilidade da Petrobras, que pode passar a ser negativa. Ele contraria o aprovado no referendo e o previsto na Lei de Hidrocarbonetos n. 3.058, de 17 de maio de 2005, que limita o government take a 50\%. Mais uma vez, um decreto revoga o disposto em lei, incidindo em inconstitucionalidade.

As empresas estrangeiras serão meras operadoras de produção e receberão 18\% da YPFB a título de remuneração. A "recuperação completa" do gás e petróleo deve ser efetuada no marco de auditorias que definirão o government take, a apropriação da parte do Estado da renda auferida pelas empresas estrangeiras com a prospecção, exploração e comercialização de hidrocarbonetos, mas não a indenização cabível em caso de expropriação: "O Ministério dos Hidrocarbonetos e Energia determinará, caso a caso e mediante auditorias, os investimentos realizados pelas companhias, assim como suas amortizações, custos de operação e rentabilidade obtida em cada campo. Os resultados das auditorias servirão de base à YPFB para determinar a retribuição ou participação definitiva correspondente às companhias nos contratos a serem assinados de acordo com o estabelecido no art. $3^{\circ}$ do presente Decreto Supremo" (Decreto Supremo n. 28.701/06, art. $4^{\circ}$, inciso III). ${ }^{105}$ As empresas estrangeiras podem permanecer operando na Bolívia, desde que se ajustem ao novo patamar de government take, a ser definido mediante auditoria.

O Estado boliviano passa a capitanear com exclusividade a prospecção, exploração e comercialização de hidrocarbonetos: "O Estado assume o controle e a direção da produção, transporte, refino, armazenagem, distribuição, comercialização e industrialização de hidrocarbonetos no país" (Decreto Supremo n. 28.701/06, art. $5^{\circ}$

1:1 Decreto Supremo n. 28.701, de $1^{\circ}$ de maio de 2006, art. $4^{\circ}$, inciso I: "Durante el periodo de transición. para los campos cuya producción certificada promedio de gas natural del año 2005 haya sido superior a los 100 millone's de pies cúbicos diarios, el valor de la producción se distrilhuirá de la siguiente forma. $82 \%$ para el Estado (18\% de regalias y participaciones. $32 \%$ de Impuesto Directo a los Hidrocarburos. IDH y 32\% a través de una participación adicional para YPFB), y 18\% para las compañias (que cubre costos de operación. amortización de inversiones y utilidades)"

1.. Decreto Supremo n. 28.701, de $1^{\circ}$ de maio de 2006. art. $4^{\circ}$, inciso III: "El Ministerio de Hidrocarburos y Energia determinará, caso por caso y mediante auditorias. las inversiones realizadas por las compañias. usi como sus umortizaciones, costos de operación y rentabilidad obrenida en cada campu. Los resultados de las auditorias servirán de base a YPFB para determinar la retribución o participación definitivu correspondiente a las compañias en los contratos a ser firmados de acuerdo a lo establecido en el Ariculo 3 del presuntc Decreto Supremo". 
inciso l). ${ }^{106}$ "O Estado recupera sua plena participação em toda a cadeia produtiva do setor de hidrocarbonetos" (Decreto Supremo n. 28.701/06, art. $7^{\circ}$ inciso I). ${ }^{107}$ Para que se assegurem meios para que o Estado cumpra esta missão, anuncia-se a nacionalização das empresas estrangeiras sem indenização, o que poder ser considerado uma modalidade de expropriação: "Nacionalizam-se as ações necessárias para que a YPFB controle com um mínimo de $50 \%$ mais 1 as empresas Chaco S.A., ${ }^{108}$ Andina S.A., ${ }^{109}$ Transredes S.A., ${ }^{10}$ Petrobras Bolivia Refinación S.A e Compañía Logística de Hidrocarburos de Bolivia S.A. "'l“ (Decreto Supremo n. 28.701/06, art. $7^{\circ}$ inciso II). ${ }^{112} \mathrm{~A}$ Petrobras Bolivia Refinación S.A. opera duas refinarias na Bolivia, uma em Santa Cruz de la Sierra e outra em Cochabamba. Elas são as mais importantes do país e passaram ao controle da empresa estatal local: "YPFB nomeará imediatamente seus representantes e síndicos nos respectivos diretórios e assinará novos contratos de sociedade e administração nos quais se garanta o controle e a direção estatal das atividades hidrocarburíferas no país" (Decreto Supremo n. 28.701/06, art. $7^{\circ}$ inciso III). ${ }^{113} \mathrm{~A}$ "recuperação completa" do gás e petróleo não compreende a nacionalização das jazidas de gás e petróleo, que não haviam sido desnacionalizadas. As empresas estrangeiras haviam obtido mediante licitação pública internacional a concessão do direito de lavra e da reserva, mas nenhuma empresa estrangeira detinha a propriedade das jazidas de gás e petróleo.

\section{Responsabilidade internacional}

A responsabilidade internacional dos Estados tem conseqüências diretas e imediatas para as empresas que têm presença no Exterior. Ela não diz respeito necessariamente ao descumprimento de acordos internacionais. No precedente "The

106 Decreto Supremo n. 28.701, de $1^{\circ}$ de maio de 2006, art. 5, inciso I: "El Estado toma el control y la dirección de la producción. Iransporte, refinación. almacenaje, distribución, comercialización $\epsilon^{\prime}$ industrialización de hidrocarburos en el pais".

107 Decreto Supremo n. 28.701, de $1^{\circ}$ de maio de 2006, art. $7^{\circ}$, inciso I: "El Estado recupera su plena participación en toda la cadena productiva del sector de hidrocarburos"

108 A Chaco S.A. é controlada pela British Petroleum.

109 A Andina S.A. é uma filial da espanhola Repsol.

110 A Transredes S.A. está ligada à anglo-holandesa Shell e à americana Enron.

III A Compañia Logistica de Hidrocarburos de Bolivia S.A. é controlada pela alemã Oiltanking (imbH.

112 Decretu Supremo n. 28.701, de $1^{\circ}$ de maio de 2006, art. $7^{\circ}$, inciso II: "Se nacionalizan las acciones necesarias para que YPFB controle como minimo el $50 \%$ más I en las empresas Chaco S.A.. Andina S.A.. Transredes S. A., Petrobras Bolivia Refinación S.A. y Compañia Logistica de Hidrocarburos de Bolivia S.A."

11: Decreto Supremo n. 28.701, de $1^{\circ}$ de maio de 2006, art. $7^{\circ}$, inciso III: "YPFB nombrará inmedialamente a sus representantes y sindicos en los respectivos directorios y firmara muevos contratos de sociedad $y$ administración en los que se garantice el control "r la dirección estatal de las actividades hidrocarburiferas en el pais" 
Mavrommatis Palestine Concessions" o Tribunal Permanente de Justiça Internacional estabeleceu: "Constitui um princípio elementar de Direito Internacional que um Estado tem o direito de proteger seus súditos, quando prejudicados por atos contrários ao direito internacional cometidos por outro Estado, do qual eles não puderam obter satisfação através dos canais habituais. Ao assumir o caso de um de seus súditos e ao recorrer a ação diplomática ou procedimentos judiciais internacionais em seu benefício, um Estado está em realidade afirmando seus próprios direitos seus direitos de assegurar, na pessoa de seus súditos, respeito pelas normas de direito internacional". 114

Muitas controvérsias diplomáticas com relação a empresas que operam no exterior já surgiram pelos mais variados motivos. Se uma empresa for prejudicada no exterior de uma maneira que haja violação do Direito Internacional, ela deve contatar o Ministério das Relações Exteriores. Se seu Estado vai defendê-la, isto depende de seus interesses e de suas conveniências políticas. Não há, sob o ponto de vista do Direito Internacional, nenhum direito da empresa que se considerar prejudicada de obrigar seu Estado a ajuizar uma reclamação internacional em seu favor. O ajuizamento de uma reclamação internacional pode ser um ensejo para que os Estados cheguem a um acordo mediante negociação diplomática. O Estado que prejudicou a empresa que opera no exterior pode admitir responsabilidade e pagar indenização.

A empresa deve atestar sua nacionalidade como nacional do Estado reclamante e esgotar os recursos jurídicos do Estado reclamado, que responderá pelo ilícito. A nacionalidade da empresa costuma depender de sua sede social e do que é previsto no ordenamento jurídico do Estado no qual ela está organizada. Os recursos jurídicos do Estado reclamado devem estar efetivamente disponíveis, devem ser factíveis. Não é necessário esgotar estes recursos jurídicos se eles não forem efetivos ou se não for relevante ter-lhes acesso: "Não deve ser necessário recorrer aos tribunais locais se tais tribunais não têm nenhuma jurisdição para conceder auxílio; nem é necessário novamente recorrer a tais tribunais se o resultado tem de ser uma repetição de uma decisão já prolatada" "1" Dificilmente tribunais bolivianos contrariarão o previsto no

it Tribunal Permanente de Justiça Intemacional (TPJI). The Mavrommatis Palestine Concessions Case. Ser. A, N. 2, 1924. Grécia versus Reino Unido. 30 ago. 1924, p. 12: "It is an elementary principle of international law that a State is entitled to protect its subjects, when injured by acts contrary to international law committed by another State, from whom they have been unable to obtain satisfaction through the ordinary channels. By taking up the case of one of its subjects and by resorting to diplomatic action or international judicial proceedings on his behalf, a State is in reality asserting its own rights - its rights to ensure, in the person of its subjects, respect for the rules of international law".

IIs Tribunal Permanente de Justiça Internacional (TPJI). The Panevezys-Saldutiskis Railway Case. Ser. A/B, N. 76, 1939. Estônia versus Lituânia. 28 fev. 1939, p. 18: "There can be no need to resort to the municipal courts if those courts have no jurisdiction to afford relief: nor is it necessary again to resort to those courts if the result must be a repetition of a decision already given" 
Decreto Supremo n. 28.701, de $1^{\circ}$ de maio de 2006. Se o Brasil pretender apresentar uma reclamação intemacional em favor da Petrobras demandando indenização por sua expropriação, o Estado não deve exigir da Petrobras que ela esgote os recursos jurídicos da Bolívia.

Para que um Estado tenha de pagar indenização ao reconhecer-se sua responsabilidade internacional num caso concreto, é preciso que sejam desrespeitadas normas de Direito Internacional, e não de Direito nacional, local. Deve haver uma conduta ilícita sob o ponto de vista internacional. Quando há uma anulação ou violação de um contrato entre uma empresa estrangeira e um Estado, seria possivel, então, reconhecer sua responsabilidade internacional? Se o contrato é regido pelo Direito nacional, local, haveria o desrespeito a normas de Direito Internacional? A resposta a tais questionamentos é positiva. Se o contrato é anulado ou violado arbitrariamente, se houve confisco da propriedade pertencente a empresa estrangeira, pode ser reconhecida a responsabilidade do Estado com base na violação de normas de Direito Internacional.

Se há expropriação de empresa estrangeira, suas instalações precisam ser indenizadas. É o que prevê, por exemplo, o precedente Selwyn, do Tribunal Arbitral: "O ato do governo pode ter ocorrido em função das mais importantes razões de política pública e com a mais alta consideração pelo Estado e seus interesses; mas quando em virtude da necessidade ou política do governo ele se apropria ou destrói a propriedade ou direitos de propriedade de um estrangeiro. ele deve indenizar de maneira adequada e completa" "116 A mesma posição foi adotada pelo Tribunal Arbitral Misto no precedente Goldenberg: "Se o direito internacional autoriza um Estado por motivos de utilidade pública a derrogar o princípio do respeito pela propriedade privada de estrangeiros, é apenas sob a condição sine qua non de que a propriedade requisitada ou expropriada seja paga de uma maneira justa tão rápido quanto possível" "A expropriação de empresa estrangeira é lícita se for paga uma indenização adequada, efetiva e pronta.

A Resolução n. 1803 (XVII) da Assembléia Geral das Nações Unidas. de 14 de dezembro de 1962, intitulada "Soberania Permanente sobre os Recursos Naturais".

11" Tribunal Arbitral. Selwyn Case, 1903: "The act of the Government may have proceeded from the highest reasons of public policy and with the largest regard for the state and its interests; but when from the necessity or policy of the Government it appropriates or destroys the property or property rights of an alien it is held to make full and adequat' compensation therefor" (Cf. BISHOP, William W. Jr. General course of public international law. In: Recueil de cours: collected courses of The Hague Academy of International Law 1965-II. Leiden: A.W. Sijthoff, 1965, v. 115. p. 405).

11: Tribunal Arbitral Misto. Goldenberg Case, 1928: "If international law authorizes a State for motives of public utility to derogate from the principle of respect for the private property of aliens. it is on the condition sinc qua non that the expropriated or requisitioned property will be paid for fairly as quickly as possible" (Cf. BISHOP. William W. Jr. General course of public international law. In: Recueil de cours: collected courses of The Hague Academy of International Law 1965-II. Leiden: A.W. Sijthoff, 1965, v. 115. p. 405-406). 
reconhece o direito de todo Estado de dispor de seus recursos naturais conforme seus interesses com o objetivo de fortalecer sua independência econômica. É possível autorizar. limitar ou proibir as atividades de empresas estrangeiras interessadas na exploração de tais recursos. ${ }^{118}$ Em caso de nacionalização ou expropriação de empresa estrangeira. mesmo que fundamentada em utilidade pública, o Estado deve de qualquer maneira pagar uma indenização. "A nacionalização, a expropriação ou a requisição deverão estar fundamentadas em razões ou motivos de utilidade pública, de segurança ou de interesse nacional, nos quais se reconhece como superiores ao mero interesse particular ou privado. tanto nacional quanto estrangeiro. Nestes casos, será pago ao dono a indenização correspondente, conforme as normas em vigor no Estado que adote estas medidas em exercício de sua soberania e em conformidade com o Direito Internacional. Em qualquer caso em que a questão da indenização dê origem a um litígio, deve-se esgotar a jurisdição nacional do Estado que adote estas medidas. Não-obstante. por acordo entre Estados soberanos e outras partes interessadas, o litígio poderá ser julgado por arbitragem ou tribunal judicial internacional" 119

\section{Conclusão}

Como podemos verificar ao longo deste artigo, a Bolivia foi o primeiro país sul-americano a nacionalizar seus hidrocarbonetos, em 1937. medida que voltou a repetir-se em 1969. Agora, estaríamos diante da terceira e definitiva nacionalização do gás e petróleo. Não há, no entanto, uma nova nacionalização estrito senso, mas, como tivemos a oportunidade de demonstrar, uma expropriação de empresas estrangeiras. A Constituição da Bolívia assegura, como podemos ressaltar, que as jazidas de gás e petróleo pertencem ao Estado.

A expropriação das empresas estrangeiras que operam na Bolívia viola contratos celebrados ao amparo do Direito boliviano vigente à época. O Estado assumiu o controle acionário da Petrobras Bolivia Refinación S.A. A YPFB, representando o Estado boliviano, assumiu a comercialização dos hidrocarbonctos, definindo as condições, volumes e preços de sua industrialização e exportação. $O$ aumento do government take de $50 \%$ para $82 \%$ pode inviabilizar o funcionamento da Petrobras na

118 Resolução n. 1803 (XVII) da Assembléia Geral das Nações Unidas, de 14 de dezembro de 1962. "Soberania Permanente sobre os Recursos Naturais", art. 20: "A exploração, o desenvolvimento e a disposição de tais ricursos, assim como a importação de capital estrangeiro para efetivá-los. deverão estar em conformidade com as regras e condições que estes povos e nações livremente considerem necessários ou desejáveis para auturizar, limitar ou proibir tais atividades"

119 Resolução n. 1803 (XVII) da Assembléia Geral das Nações Unidas, de 14 de dezembro de 1962. "Soberania Permanente sobre os Recursos Naturais". art. $4^{\circ}$ 
Bolívia. Este aumento é provisório e pode voltar a ser discutido após a realização de auditorias, mas $50 \%$ já seriam confisco. As empresas que não estiverem de acordo com a "recuperação total" do gás e petróleo têm somente 180 dias para revisar os contratos a partir da promulgação do Decreto Supremo n. 28.701, de $1^{\circ}$ de maio de 2006. A Petrobras é a empresa estrangeira mais prejudicada, pois é a com maior presença na Bolívia. A "recuperação completa" do gás e petróleo foi anunciada pelo presidente Evo Morales no campo de San Alberto, o mais importante da Bolívia, operado pela Petrobras. A Petrobras tem uma carga altamente simbólica na Bolívia. Com cerca de US\$ 1 bilhão investido, é responsável por $15 \%$ do Produto Interno Bruto (Pib) boliviano. ${ }^{120}$

Não deve ser fácil para a Petrobras renegociar contratos com a Bolívia após suas instalações terem sido ocupadas manu militari. Contratos que foram celebrados com o Estado boliviano, ao que tudo indica, podem não ter segurança jurídica. A reação do Brasil, podendo inclusive recorrer ao Tribunal Internacional de Justiça, ao que aconteceu com a Petrobras será fundamental também para outras empresas brasileiras que atravessam um intenso processo de internacionalização de suas atividades. Se o Brasil não defender adequadamente o interesse de suas empresas públicas estabelecidas no Exterior, isto pode ser entendido pelas empresas privadas como um sinal de que, em se tratando de empresas que não forem públicas, o empenho para defender seus interesses será menor ainda. Elas podem, então, sentir-se tentadas a transferir sua sede social para países que se tenham mostrado mais comprometidos $\mathrm{cm}$ proteger o patrimônio de seus cidadãos fora de seu território nacional.

São Paulo, fevereiro de 2006.

Referências

ALCÁZAR, Moisés. Abel Iturralde, el centinela del petróleo. 2. ed. La Paz: Libreria Editorial "Juventud" 1982.

ANDFRSON, David. Negotiation and dispute settlement. In: EVANS, Malcolm D. (F.d.). Remedies in international law: the institutional dilemma. Oxford: Hart Publishing, 1998. p. 111140.

ARIAS, Alejandro Mansilla. Apuntes de geopolitica. Santa Cruz de la Sierra: Editorial El País. 2003.

120 A Petrobras desenvolveu as jazidas de gás bolivianas, a segunda maior do continente sul-americano. garantindo infra-estrutura e mercado para suas exportações. Durante os primeiros anos de cumprimento do contrato de compra-e-venda du gás natural, a Petrobras comercializou o gás boliviano com perdas. 
ARRARÁS, Astrid; DEHEZA, Grace. Referéndum del gas en Bolivia 2004: mucho más que un referéndum. Revista de Ciencia Politica, Santiago do Chile,v. 25, n. 2, p. 161-172, 2005.

BISHOP, William W. Jr. General course of public international law. Recueil de cours: collected courses of The Hague Academy of International Law 1965-II. Leiden, v. 115, p. 384-422, 1965.

BISHOP, William W. Jr. International law cases and materials. 3. ed. Boston/Toronto: Little. Brown and Company, 1971. p. 742-899.

BROWNLIE. Ian. Principios de direito internacional público. Lisboa: Fundação Calouste Gulbenkian. 1997. p. 457-531.

BRY, Georges. Précis élémentaire de droit international public mis au courant des progrès de la science et du droit positif contemporain. 6. ed. rev. Paris: Recueil Sirey, 1910. p. 105-190.

C.APOTORTI, Francesco. Cours général de droit international public. Recueil de cours: collected courses of The Hague Academy of International Law 1994-IV. Dordrecht/Boston/Londres, v. 248. p. 239-274, 1995.

FERREYRA, Christian. Un análisis crilico del referéndum vinculante sobre los hidrocarburos. Cochabamba: Centro de Documentación e Información Bolivia, 27 maio 2004.

FERREYRA, Christian. Referéndum y nacionalización de los hidrocarburos. Cochabamba: Centro de Documentación e Información Bolivia, 17 junho 2004.

GISBERT, Carlos D. Mesa. Presidentes de Boliviu, entre mnas y fusiles. 3. ed. La Paz: Editorial Gisbert, 2003.

HIGGINS, R. General course on public intemational law. Recueil de cours: collected courses of The Haguc Academy of International Law 199I-V. Dordrecht/Boston/Londres, v. 230, p. 195-222. 1993.

JENNINGS, R.Y. General course on principles of intemational law. Recueil de cours: collected courses of The Hague Academy of International Law 1967-II, Leiden, v. 121. p. 473-514, 1969.

MALANCZUK, Peter. Akehurst's modern introduction 10 international lan: 7. ed. rev. Londres/Nova York: Routledgc, 1997. p. 254-425.

QUIGLEY, John. Complicity in international law: a new direction in the law of state responsihility. The hritish vearbook of international law 1986, Oxford. p. 77-131, 1987.

VERZIJL. J.H.W. International law in historical perspective. Leiden: A. W. Sijthoff, 1908. v. I, p. 244-255. 